\title{
Making sense of the "clean label" trends: a review of consumer food choice behavior and discussion of industry implications
}

Article

Accepted Version

Creative Commons: Attribution-Noncommercial-No Derivative Works 4.0

Asioli, D., Aschemann-Witzel, J., Caputo, V., Vecchio, R., Annunziata, A., Naes, T. and Varela, P. (2017) Making sense of the "clean label" trends: a review of consumer food choice behavior and discussion of industry implications. Food Research International, 99 (1). pp. 58-71. ISSN 0963-9969 doi: https://doi.org/10.1016/j.foodres.2017.07.022 Available at https://centaur.reading.ac.uk/75793/

It is advisable to refer to the publisher's version if you intend to cite from the work. See Guidance on citing.

To link to this article DOI: http://dx.doi.org/10.1016/j.foodres.2017.07.022

Publisher: Elsevier

All outputs in CentAUR are protected by Intellectual Property Rights law, including copyright law. Copyright and IPR is retained by the creators or other copyright holders. Terms and conditions for use of this material are defined in the End User Agreement. 


\section{CentAUR}

Central Archive at the University of Reading

Reading's research outputs online 
Please cite as: Asioli, Daniele; Aschemann-Witzel, Jessica; Caputo, Vincenzina; Vecchio, Riccardo; Annunziata, Azzurra; Næs, Tormod; Varela, Paula. Making sense of the "clean label” trends: a review of consumer food choice behavior and discussion of industry implications Food Research International, 99, 58-71. https://doi.org/10.1016/j.foodres.2017.07.022

\title{
Making sense of the "clean label” trends: a review of consumer food choice behavior and discussion of industry implications
}

\author{
Daniele Asioli ${ }^{1, \mathrm{a}, \mathrm{b}, \mathrm{h}}$ \\ Jessica Aschemann-Witzel ${ }^{\mathrm{C}}$ \\ Vincenzina Caputo ${ }^{\mathrm{d}}$ \\ Riccardo Vecchio ${ }^{\mathrm{e}}$ \\ Azzurra Annunziata ${ }^{\mathrm{f}}$ \\ Tormod Næs $\mathrm{s}^{\mathrm{a}, \mathrm{g}}$ \\ Paula Varela ${ }^{\mathrm{a}}$
}

${ }^{\text {a }}$ Consumer and Sensory Science - Division of Food Science - NOFIMA AS, Ås, Norway.

${ }^{\mathrm{b}}$ School of Economics and Business, Norwegian University of Life Sciences, Ås, Norway.

${ }^{\mathrm{c}}$ MAPP Centre - Research on Value Creation in the Food Sector, Aarhus University, Aarhus, Denmark.

${ }^{\mathrm{d}}$ Department of Agricultural, Food and Resources Economics, Michigan State University, East Lansing, United States.

e Department of Agricultural Sciences, University Federico II, Naples, Italy.

${ }^{\mathrm{f}}$ Department of Economic and Legal Studies, University of Naples Parthenope, Naples, Italy.

${ }^{\mathrm{g}}$ Department of Food Science - University of Copenhagen,, Copenhagen, Denmark.

${ }^{\mathrm{h}}$ Department of Agricultural Economics and Agribusiness, University of Arkansas, Fayetteville, United States.

${ }^{1}$ Corresponding author.

Tel: + 47649701 65. Fax: +47 64970333

Email: daniele.asioli@nofima.no 
Please cite as: Asioli, Daniele; Aschemann-Witzel, Jessica; Caputo, Vincenzina; Vecchio, Riccardo; Annunziata, Azzurra; Næs, Tormod; Varela, Paula. Making sense of the "clean label” trends: a review of consumer food choice behavior and discussion of industry implications Food Research International, 99, 58-71. https://doi.org/10.1016/j.foodres.2017.07.022

\begin{abstract}
Consumers in industrialized countries are nowadays much more interested in information about the production methods and components of the food products that they eat, than they had been 50 years ago. Some production methods are perceived as less "natural” (i.e. conventional agriculture) while some food components are seen as "unhealthy” and "unfamiliar” (i.e. artificial additives). This phenomenon, often referred to as the "clean label”' trend, has driven the food industry to communicate whether a certain ingredient or additive is not present or if the food has been produced using a more "natural” production method (i.e. organic agriculture). However, so far there is no common and objective definition of clean label. This review paper aims to fill the gap via three main objectives, which are to a) develop and suggest a definition that integrates various understandings of clean label into one single definition, b) identify the factors that drive consumers' choices through a review of recent studies on consumer perception of various food categories understood as clean label with the focus on organic, natural and 'free from' artificial additives/ingredients food products and c) discuss implications of the consumer demand for clean label food products for food manufacturers as well as policy makers. We suggest to define clean label, both in a broad sense, where consumers evaluate the cleanliness of product by assumption and through inference looking at the front-of-pack label and in a strict sense, where consumers evaluate the cleanliness of product by inspection and through inference looking at the back-of-pack label. Results shows that while 'health' is a major consumer motive, a broad diversity of drivers influence the clean label trend with particular relevance of intrinsic or extrinsic product characteristics and socio-cultural factors. However, 'free from' artificial additives/ingredients food products tend to differ from organic and natural products. Food manufacturers should take the
\end{abstract}


Please cite as: Asioli, Daniele; Aschemann-Witzel, Jessica; Caputo, Vincenzina; Vecchio, Riccardo; Annunziata, Azzurra; Næs, Tormod; Varela, Paula. Making sense of the "clean label”, trends: a review of consumer food choice behavior and discussion of industry implications Food Research International, 99, 58-71. https://doi.org/10.1016/j.foodres.2017.07.022

diversity of these drivers into account in developing new products and communication about the latter. For policy makers, it is important to work towards a more homogenous understanding and application of the term of clean label and identify a uniform definition or regulation for 'free from' artificial additives/ingredients food products, as well as work towards decreasing consumer misconceptions. Finally, multiple future research avenues are discussed.

KEY WORDS: clean label, consumer preferences, food industry, review, drivers, trend, food products.

\section{INTRODUCTION}

During the last century, industrialized countries have overcome lack of food security with the key contribution of agrifood industrialization (Lusk, 2016; Meneses, Cannon, \& Flores, 2014). Food processing has played a crucial role as it allowed extending the shelf life of food products, reduced food losses and waste, as well as improved nutrient availability and optimization (Augustin et al., 2016; Fellows, 2004; Weaver et al., 2014). However, day-to-day consumer perception focuses on other aspects than these achievements. In modern societies, the increasingly globalized markets and greater processing in the food chain has contributed to a perceived distance and knowledge gap between people and food manufacturers (e.g. how food is produced, where is it produced, etc.) (Princen, 1997; Weis, 2007).

Industrialization and globalisation go hand in hand with a higher and more man-made risk, which increases citizens’ perception of risks of modernity (Beck, 1992). For instance, food contamination accidents have affected Europe in the last decades, such as BSE ${ }^{2}$ and dioxin (Bánáti, 2011;

\footnotetext{
${ }^{2}$ Bovine Spongiform Encephalopathy.
} 
Please cite as: Asioli, Daniele; Aschemann-Witzel, Jessica; Caputo, Vincenzina; Vecchio, Riccardo; Annunziata, Azzurra; Næs, Tormod; Varela, Paula. Making sense of the "clean label” trends: a review of consumer food choice behavior and discussion of industry implications Food Research International, 99, 58-71. https://doi.org/10.1016/j.foodres.2017.07.022

Knowles, Moody, \& McEachern, 2007). Consumers are concerned about the heavy use of pesticides in the conventional and intensive agricultural practices (Aktar, Sengupta, \& Chowdhury, 2009), the use of artificial ingredients, additives or colorants such as E133 (Lucová, Hojerová, Pažoureková, \& Klimová, 2013), and the adoption of controversial food technologies like GMOs ${ }^{3}$ (Grunert, Bredahl, \& Scholderer, 2003). This has prompted consumers to become skeptical or worried about adverse health effects entailed in this food system (Meneses et al., 2014). Moreover, the growing public concern about the contribution of the food system to climate change and its overall negative effects on sustainability (Godfray et al. 2013) have led consumers to question the environmental and social consequences of food production (Asioli et al., 2014; Caputo, Nayga, \& Scarpa, 2013).

Consumer's choose foods to be satiated and fed with nutrients, other important drivers are flavour and price (Lynn Jayne Frewer \& van Trijp, 2007; MacFie, 2007). However, it is often proposed that today's food consumption in industrialized societies is particularly affected by three major trends: health concerns, sustainability, and convenience (Grunert, 2013). Health concerns are driven by consumers' affluence, but also explained by the increasing number of food and lifestyle related diseases (i.e. diabetes, obesity, etc.) (Kearney, 2010; Weis, 2007) and allergies and intolerances towards some specific food products or components such as gluten. These factors have encouraged consumers to be more interested in healthy food products that support healthy lifestyles into older ages and reduce the risk of certain diseases. Sustainability interest is explained by the growing awareness of environmental pollution caused by conventional agricultural practices. This has resulted most prominently in an increased expansion of organic agriculture and markets

\footnotetext{
${ }^{3}$ Genetically Modified Organisms.
} 
Please cite as: Asioli, Daniele; Aschemann-Witzel, Jessica; Caputo, Vincenzina; Vecchio, Riccardo; Annunziata, Azzurra; Næs, Tormod; Varela, Paula. Making sense of the "clean label” trends: a review of consumer food choice behavior and discussion of industry implications Food Research International, 99, 58-71. https://doi.org/10.1016/j.foodres.2017.07.022

(Aschemann, Hamm, Naspetti, \& Zanoli, 2007) and might also explain why consumers are looking for e.g. 'local food' products (food miles) (Adams \& Salois, 2010) and are willing to pay higher prices for water-saving products (Krovetz, 2016). Convenience relates to the number of meals that are eaten out-of-home or home-delivered compared to home-made. This number has dramatically increased during the last decades (Lachat et al., 2012), which signifies that consumers are interested in added characteristics of food products that save time (e.g. frozen food, ready meals, microwavable, etc.).

The trends of healthiness and sustainability have triggered consumers into considering which components are used in the food products that they eat in everyday life (Euromonitor International, 2016). A new trend in food products has emerged, which is often summarized under the umbrella of the so-called “clean label” (Cheung et al., 2015; Joppen, 2006; Varela \& Fiszman, 2013; Zink, 1997) and has been taken up by a multitude of food industry stakeholders (Osborne, 2015). The term clean label itself appeared for the first time during the 1980s when consumers started to avoid the E-numbers ${ }^{4}$ listed on food labels because they were allegedly associated with negative health effects (Joppen, 2006). However, the use of the term clean label dramatically exploded ten years ago. One of the leading food science journals, “Food Technology Magazine,” cited the term “clean label' twice in 2000, 18 times in 2011 and 77 times in 2016 in their articles, clearly indicating a growing importance of the term (Swientik, 2017).

The food industry has started to respond to the increasing consumer demand of such clean label products by supplying food products that are perceived as 'cleaner' (Katz \& Williams, 2011). For

\footnotetext{
${ }^{4}$ E-numbers are the code numbers used to identify food additives in EU. E-numbers have been shown to be safe and officially approved for use in food across the EU (i.e. E202 is the Potassium sorbate) (Emerton \& Choi, 2008). This nomenclature has been extended worldwide to the Codex Alimentarius Commission (Carocho et al., 2014).
} 
Please cite as: Asioli, Daniele; Aschemann-Witzel, Jessica; Caputo, Vincenzina; Vecchio, Riccardo; Annunziata, Azzurra; Næs, Tormod; Varela, Paula. Making sense of the "clean label” trends: a review of consumer food choice behavior and discussion of industry implications Food Research International, 99, 58-71. https://doi.org/10.1016/j.foodres.2017.07.022

example, in 2010 Heinz tomato ketchup was reformulated to remove high fructose corn syrup from the ingredient list and was renamed as Simply Heinz (Katz \& Williams, 2011). Recent data shows that during 2013, almost 27\% of the new packaged food products launched in Europe had some sort of clean label (Ingredion, 2014).

Despite the increasing market shift toward clean label food products and a large number of different studies that have investigated goods carrying clean label, it is not yet clear what a clean label exactly means. So far, a jointly agreed upon definition or specific regulations/legislations does not exist (Busken, 2013; Joppen, 2006; Varela \& Fiszman, 2013), leaving the interpretation as rather subjective for consumers and food practitioners. A clear definition of clean label that can improve understanding of consumer perception and behavior, guide manufacturers in food development and communication, and support policymakers' efforts in providing a targeted regulatory framework is needed (Katz \& Williams, 2011). Moreover, to the best knowledge of the authors, a coherent overview of the factors that affect consumers' perception of food products that are related to the clean label trend does not exist (Cheung et al., 2015; Zink, 1997).

This paper reviews the literature from the last six years on consumers' perceptions and preferences of selected food categories understood as clean label products, aiming to (i) provide a holistic definition that integrates various understandings of clean label into one single definition; (ii) identify the main drivers that motivate consumers to choose clean label products, and (iii) derive implications for food manufacturers, policy makers and future research avenues. The overall goal of this paper is to advance the understanding of how the clean label trend is viewed by both consumers and food industry professionals and to advance research into this trend based on a common definition. 
Please cite as: Asioli, Daniele; Aschemann-Witzel, Jessica; Caputo, Vincenzina; Vecchio, Riccardo; Annunziata, Azzurra; Næs, Tormod; Varela, Paula. Making sense of the "clean label” trends: a review of consumer food choice behavior and discussion of industry implications Food Research International, 99, 58-71. https://doi.org/10.1016/j.foodres.2017.07.022

In section 2, we briefly describe some important theoretical issues related to consumer behavior as background for understanding the basic processes of consumer decision making. Then, we suggest a definition of clean label based on consumption trends observed in various food markets and the underlying consumer behavior theory. We then outline the literature review methodology and present the results of the review on the factors that affect consumers' choice behavior for such products. The paper concludes with a discussion of industrial and policymakers' challenges, the implications of the findings, and future research needs and directions.

\section{CONSUMER BEHAVIOR THEORETICAL BACKGROUND}

Looking at related theories or theoretical terms can help understanding why consumers show an increasing interest in clean label, and it can help to understand the role that consumer perception plays in explaining this trend. We regard two distinctions as particularly relevant for explaining the consumer behavior driving the clean label trend. Firstly, we consider dual-processing theories which differentiate between two modes of processing called central and peripheral processing. Secondly, we consider the distinction of goals as either approach or avoidance goals, and the related individual trait of being oriented towards promotion or prevention orientation. Both will be briefly introduced and their contribution to explaining consumer interest in clean label products discussed. Afterwards, when presenting our definition and categorization of clean label, we will refer to these theories to support the categories of clean label that we suggest. 
Please cite as: Asioli, Daniele; Aschemann-Witzel, Jessica; Caputo, Vincenzina; Vecchio, Riccardo; Annunziata, Azzurra; Næs, Tormod; Varela, Paula. Making sense of the "clean label” trends: a review of consumer food choice behavior and discussion of industry implications Food Research International, 99, 58-71. https://doi.org/10.1016/j.foodres.2017.07.022

\subsection{Dual-processing theory}

It is broadly acknowledged that consumer food choices are typically conducted in an environment of information overload (Mick, Broniarczyk, \& Haidt, 2004). This holds true even more today than 5 - 10 years ago, given that supermarket assortments are growing and the simultaneous use of multiple media for information access and for marketing communication is increasingly widespread (Dholakia et al., 2010). Involvement with food overall differs greatly depending on the individual's value orientation or the relevance of food for expression of lifestyle, personality, or identity (Brunsø \& Grunert, 1995; Eertmans, Victoir, Vansant, \& den Bergh, 2005; Thøgersen, 2017). However, for most consumers - at least from industrialized and developed countries -, each single food choice has little impact on household budget and is repeated very often, which furthers habitual and routine choice decision processes to economize efforts (Hoyer, 1984). In addition, the situational context often impedes spending cognitive resources on engaging in deep processing of information about the product (Mick et al., 2004). Due to these reasons, food choices are often depicted as conducted in a low involvement situation (Beharrell \& Denison, 1995; Gilles Laurent, 1985; Knowx \& Walker, 2003). Thus, consumers are ascribed low motivation, and, in addition, it is assumed that the choice context results in consumers' low ability or opportunity to process information. According to dual processing theories (Evans, 2003) such as the elaboration-likelihood model (Kitchen, Kerr, Schultz, McColl, \& Pals, 2014; Petty, Cacioppo, \& Schumann, 1983), this means that food consumers typically process the greater share of information about foods peripherally and not centrally, that they more likely rely on using informational or visual cues that allow inferences and thus a 'short-cut' to a judgment, and that they often are not conscious of the heuristics they apply. 
Please cite as: Asioli, Daniele; Aschemann-Witzel, Jessica; Caputo, Vincenzina; Vecchio, Riccardo; Annunziata, Azzurra; Næs, Tormod; Varela, Paula. Making sense of the "clean label” trends: a review of consumer food choice behavior and discussion of industry implications Food Research International, 99, 58-71. https://doi.org/10.1016/j.foodres.2017.07.022

With regard to the clean label trend, we argue that hints about the item being a clean label food are used as such cues. We argue that their easy usage and inference to desirable, but unobservable characteristics explains the popularity of clean label. Typically, consumers might use cues found on the front of the package (FOP) such as visuals indicating naturalness, organic certification logos, or free-from claims of producers, thus, these products might be perceived as clean label. However, we argue that not only peripheral processing is expected to play a role for clean label, but also central processing. In some cases consumers might proceed to access information on the back of the pack (BOP) in store or, even more likely, at home. There is a greater likelihood that consumers who are engaging in this effort are characterized by greater involvement and thus motivation to process, or that the situation at home provides better opportunity to look at information and engage with it, thus, identifying the product as clean label. Therefore, central, more in-depth and conscious information processing will occur more likely at home. Consumers might then look at the ingredient information or nutrition facts more closely, and inspect and assess whether or not they think the product is a clean label food in their opinion. However, given that consumers might not find this easy to assess, they might nevertheless rely on heuristics, such as the degree to which ingredient names sound chemical or are unknown, or the mere length of the ingredient list. In addition to using this observable feature as a cue to a desired quality, consumers might also favor products with understandable, short, known and simple ingredient lists in order to reduce the cognitive effort needed in assessing the product.

\subsection{Approach versus avoidance goals and regulatory focus}

Consumers make decisions for products because they have identified a need. This need motivates them into action. They are more aware of the goal of their action than of the underlying need that 
Please cite as: Asioli, Daniele; Aschemann-Witzel, Jessica; Caputo, Vincenzina; Vecchio, Riccardo; Annunziata, Azzurra; Næs, Tormod; Varela, Paula. Making sense of the "clean label” trends: a review of consumer food choice behavior and discussion of industry implications Food Research International, 99, 58-71. https://doi.org/10.1016/j.foodres.2017.07.022

had triggered it (Schiffman \& Wisenblit, 2015). Goals can be typically categorized as approach or avoidance goals; that is, goals to achieve a certain desirable state, feature or situation, or goals of avoiding those elements (Aaker \& Lee, 2001). According to regulatory focus theory, consumers might differ to the extent that they are more oriented towards actions promoting attainment of a goal or towards actions preventing something that might inhibit attainment of the goal (Higgins, 2005). When it comes to food, various researchers have suggested that consumers might be either motivated by attaining something, as for example health and well-being, or avoiding something, as for example risk of disease, a distinction that has been applied to nutrition and health claims (van Kleef, van Trijp, \& Luning, 2005). It has also been suggested that different goals can help explain different strategies in reading nutrition information (Chalamon \& Nabec, 2016). Additionally, an individual's promotion vs. prevention focus can contribute to understanding food choice of an individual (de Boer \& Schösler, 2016) or might explain impulsiveness in purchase situations (Das, 2015). The inference biases of a 'negative bias' or an 'optimism bias' are also worth mentioning in this relation. The negative bias suggests that a single ingredient perceived as negative can lead to an exaggerated negative assessments of the food as a whole (in the context of clean label, a single unfamiliar ingredient in the ingredient list to disliking the food to an extent not objectively explained by the share of and role of the said ingredient). The optimisms bias, in turn, suggests that a food ingredient perceived as positive might lead to an exaggerated positive assessment of the food as a whole (in the context of clean label, a single, sought-after ingredient that is regarded as natural causing that the food overall to be perceived as more natural, even though the share and role does not merit such a change in perception, or the food ingredients being organic leading to unfounded 'halo-effects' of assuming a range of other positive effects as well). 
Please cite as: Asioli, Daniele; Aschemann-Witzel, Jessica; Caputo, Vincenzina; Vecchio, Riccardo; Annunziata, Azzurra; Næs, Tormod; Varela, Paula. Making sense of the "clean label” trends: a review of consumer food choice behavior and discussion of industry implications Food Research International, 99, 58-71. https://doi.org/10.1016/j.foodres.2017.07.022

With regard to the clean label trend, we argue that, at first glance, some of the trends subsumed under the term of clean label might be categorized as 'approach', as for example natural or organic, while others might be categorized as 'avoidance', as for example all 'free from' claimed foods. Regulatory focus theory would suggest that consumers who give importance to one or the other might differ in their orientation, and communication to these groups should differ accordingly, in order to ensure a 'fit' (Hoyer, 1984). However, research and literature into the drivers of preference for natural and organic indicate that motivation to ‘avoid something’ plays a crucial role. For example, this might be expressed as modern health worries about new technologies and substances (Devcich, Pedersen, \& Petrie, 2007), negative attitudes to chemicals (Dickson-Spillmann, Siegrist, \& Keller, 2011), avoidance of contagion or unknown descriptors (Evans, de Challemaison, \& Cox, 2010), and skepticism towards functional foods (Aschemann-Witzel, Maroscheck, \& Hamm, 2013).

Thus, while there might be consumers looking into attaining a goal by the purchase of clean label food, we suggest that a great part of the underlying motivation is explained by avoidance and prevention, also for categories that appear rather positively phrased such as natural and organic, and even more so for the free-from category of clean label food.

\section{WHAT IS A "CLEAN LABEL"?}

To date there is no an established, objective and common definition of what a clean label is, but rather several definitions or interpretations, often provided by market trend reports but not backed up by consumer behavior research or theory (Osborne, 2015). To give an example of how clean label appears conceptualized in media, one can cite Michael Pollan. He suggested in his famous recent book In Defence of Food that consumers should not: “...eat anything with more than five 
Please cite as: Asioli, Daniele; Aschemann-Witzel, Jessica; Caputo, Vincenzina; Vecchio, Riccardo; Annunziata, Azzurra; Næs, Tormod; Varela, Paula. Making sense of the "clean label” trends: a review of consumer food choice behavior and discussion of industry implications Food Research International, 99, 58-71. https://doi.org/10.1016/j.foodres.2017.07.022

ingredients, or ingredients you can't pronounce” (Pollan, 2008). Turning to more detailed description, we find that Ingredion (2014) recommends to consumers that " $a$ 'clean label' positioned on the pack means the product can be positioned as 'natural', 'organic' and/or 'free from additives/preservatives'." The same report suggests that for food producers "using a 'clean label' positioning means using ingredients that are generally accepted by consumers - those that they might find in their kitchen cupboards. The ingredient list should be short, simple and feature minimally processed ingredients where possible. It should not include names that sound like chemicals or e-numbers." Edwards (2013) defines a clean label "by being produced free of 'chemicals' additives, having easy-to-understand ingredient lists, and being produced by use of traditional techniques with limited processing." One of the key questions is which ingredients may be part of a clean label, or, more importantly, which ingredients define a clean label product by their absence. Busken (2013) proposes that the answer to this depends on the consumer perception of an ingredient.

All of the above-mentioned definitions clearly indicate that the interpretation of a clean label is subjective as it might depend on the familiarity of the consumer with the food ingredients and/or production method, and the inferences consumer draw from this information. To illustrate, it might differ a lot which ingredient is similar to kitchen cupboard items, since traditional processing techniques and what is regarded as non-worrisome varies from country to country. Such subjectivity requires that a univocal and objective definition of clean label should integrate these varying consumer perceptions and account for studies exemplifying how consumers verbalize clean label and name associations. The above mentioned definitions or interpretations also show that some authors might describe clean label as if it links directly to certain food categories or 
Please cite as: Asioli, Daniele; Aschemann-Witzel, Jessica; Caputo, Vincenzina; Vecchio, Riccardo; Annunziata, Azzurra; Næs, Tormod; Varela, Paula. Making sense of the "clean label” trends: a review of consumer food choice behavior and discussion of industry implications Food Research International, 99, 58-71. https://doi.org/10.1016/j.foodres.2017.07.022

ingredients, while consumers' perception as resulting from the communication on the package (the nutrition label, or any other cue) in interaction with the consumer's processing and individual preferences, is the underlying key to the trend. To illustrate, the food processors can position the same food in different ways, while the same food might be distinctively perceived by different consumers. Ironically, the so-called clean label is not really a label, as producers will never be able to use "clean label” as a claim. However, the term is indeed increasingly used by food manufactures and researchers, and consumers perceive and asses how clean a label is, a representation of food products' characteristics demanded by modern consumers from industrialized societies.

For example, on clean label perceptions by consumers, it has been found that consumers try to avoid certain food products with “unfamiliar” (Moskowitz, Beckley, \& Resurreccion, 2012) artificial additives/ingredients which might be perceived as artificial chemicals, or products produced with production methods that are perceived as far from 'Mother Nature' (e.g. GMO). A recent global consumer survey indicated that the percentage of consumers who avoided at least five separate ingredients or food attributes grew from 35 \% (2015) to 53\% (2016) (Euromonitor International, 2016). This trend is confirmed by several other studies, which show that among the ten different trends affecting food industry in the new millennium there is a strong tendency of consumers to prefer foods which are organic and natural (Euromonitor International, 2016; Katz \& Williams, 2011; Sloan, 1999), without preservatives or perceived negative characteristics (i.e. high fat, high sugar, etc.). Furthermore, a recent global survey conducted by Canadian researchers which involved almost 30,000 consumers from 31 countries found that consumers infer a clean label mainly from food products that show natural, organic logos and free from artificial ingredients (Gelski, 2016). Other associations were “free from allergens”, “no GMOs”, “minimally processed”, 
Please cite as: Asioli, Daniele; Aschemann-Witzel, Jessica; Caputo, Vincenzina; Vecchio, Riccardo; Annunziata, Azzurra; Næs, Tormod; Varela, Paula. Making sense of the "clean label” trends: a review of consumer food choice behavior and discussion of industry implications Food Research International, 99, 58-71. https://doi.org/10.1016/j.foodres.2017.07.022

“simple/short ingredient lists” and "transparent packaging.” All of these associations might be relevant for some consumers to infer the cleanness of food products (Gelski, 2016).

Consumer behavior theory and respective research evidence suggest that consumers either know a product has a certain characteristic because they have sought the respective information, or assume it to have the characteristic because they infer it via some other cues believed to be indicators of the desired characteristic. Consumer behavior theory and respective research also suggests that consumers seek certain characteristics of a food, while they avoid others. Information about food ingredients can be located on the front-of-pack (FOP) or on the back-of-pack (BOP) ${ }^{5}$ of a food product. The FOP information (short claims and logos) seeks to provide consumers with simplified 'at-a-glance' information to supplement the detailed information provided BOP (ingredient list, nutrition fact panels) (Draper et al., 2013). The different types of information might be processed to lesser or greater extent peripherally versus centrally.

Accordingly, we propose that consumers can access information on clean label by looking at FOP and BOP information (Figure 1). Based on the FOP information, consumers might interpret a product as clean label, given they find information that can serve as a cue to the clean label characteristic. Thus, the characteristic is inferred by assumption and foods with textual or visual claims (i.e. “natural products”) or logos (e.g. “organic”), simple labels (e.g. “Simply Heinz”) or “free-from additives/preservatives” (e.g. “free from palm oil”) are defined as clean label products in a broad sense. Based on the BOP information, consumers interpret a product as clean label by inspection given that they are looking at the ingredients list and nutrition facts panels

\footnotetext{
${ }^{5}$ In this definition including the sides of a package.
} 
Please cite as: Asioli, Daniele; Aschemann-Witzel, Jessica; Caputo, Vincenzina; Vecchio, Riccardo; Annunziata, Azzurra; Næs, Tormod; Varela, Paula. Making sense of the "clean label” trends: a review of consumer food choice behavior and discussion of industry implications Food Research International, 99, 58-71. https://doi.org/10.1016/j.foodres.2017.07.022

communicating the clean label characteristic of reporting ingredients "short and simple”, not containing “artificial ingredients”, “not chemical-sounding”, and only containing “kitchen cupboard ingredients” which are expected to be familiar to consumers. These food products are clean label products in a strict sense.

\section{Figure 1 - A proposed definition and concept of "clean label" $<<$ Please, place here figure 1 $>>$}

From the proposed definition of clean label and the consumer research that has shown which food categories are assumed to possess characteristics related to clean label, we can identify categories of food products from which consumers can infer the 'cleanliness' of food products. In this review paper, due to space limitations, we decided to focus attention on three categories of clean label: organic, natural and ‘free from’ artificial additives/ingredients, as we argue these are the major groups of relevance (Schroeder, 2016), and that factors driving consumer perception and behaviour from this literature stream will likely be predictive for other categories of clean label.

\section{FACTORS DRIVING CONSUMERS' PERCEPTIONS AND PREFERENCES FOR CLEAN LABEL FOOD PRODUCTS}

\subsection{Methodology}

A literature search has been conducted by investigating the following four online catalogues:

Scopus, Science Direct, AgEcon Search, and Web of Science. We used the following keywords or keyword combinations: “label”, “organic”, “natural”, “free from”, “artificial”, “additives”, 
Please cite as: Asioli, Daniele; Aschemann-Witzel, Jessica; Caputo, Vincenzina; Vecchio, Riccardo; Annunziata, Azzurra; Næs, Tormod; Varela, Paula. Making sense of the "clean label” trends: a review of consumer food choice behavior and discussion of industry implications Food Research International, 99, 58-71. https://doi.org/10.1016/j.foodres.2017.07.022

“colourants”, “ingredients”, “clean label”, “consumers”, “perception”, “behaviour”, “preference”, “choice”, and "food” in the title or the abstract. The review was restricted to English-language, peer-reviewed empirical studies examining consumers' perceptions and preferences for the specific categories of clean label food products mentioned above, published in scientific journals during the last six years (2012 - 2017). The decision to limit the search to the last six years comes from the need to offer an overview of the latest studies. However, with a view to incorporating important references needed for a more comprehensive understanding of the phenomena, older references have also been included where appropriate, as well as review papers on the topic.

A total of 187 articles were found based on titles and/or abstracts (110 for organic, 46 for natural, 29 for 'free from' artificial additives/ingredients food products). Only the articles belonging to the following subject areas were extracted: social sciences, food science, sensory science, marketing, business management and economics. Finally, a total of 95 (54 for organic, 25 for natural, 16 'free from' artificial additives/ingredients food products) articles were read in full length and were included. Tables A1, A2 and A3, reported in appendix, provides a summary of selected articles respectively for organic, natural and 'free from' artificial additives/ingredients food products. For each category, a number of factors that drive consumers' perceptions and preferences of clean label food products were identified and commented on within the literature. In order to have a coherent and common way of identifying and categorising the factors, we used the well-known model proposed by Mojet (Köster, 2009) which identifies the essential categories of factors that influence eating and drinking behaviour and food choice (Figure 2).

Figure 2 - Essential factors that influence eating and drinking behaviour and food choice. 
Please cite as: Asioli, Daniele; Aschemann-Witzel, Jessica; Caputo, Vincenzina; Vecchio, Riccardo; Annunziata, Azzurra; Næs, Tormod; Varela, Paula. Making sense of the "clean label” trends: a review of consumer food choice behavior and discussion of industry implications Food Research International, 99, 58-71. https://doi.org/10.1016/j.foodres.2017.07.022

\section{$<<$ Please, place here figure 2>>}

\subsection{Factors that drive consumers' perceptions and preferences for organic labeled food products}

It is widely recognized that organic food products represent one of the fastest-growing segments of the food market in many countries around the world (FIBL, 2017; IFOAM, 2015). Organic agriculture is a production system that sustains the health of soils, ecosystems, and people. It relies on ecological processes, biodiversity, and cycles adapted to local conditions, rather than the use of inputs with adverse effects. Organic agriculture is based on principles of health, ecology, fairness, and care (IFOAM, 2015).

There is a considerable amount of literature which attempts to understand the factors affecting consumers' attitudes and preferences for organic food products using different models or frameworks (for recent reviews see Aertsens, Verbeke, Mondelaers, \& van Huylenbroeck, 2009; Hemmerling, Hamm, \& Spiller, 2015; Schleenbecker \& Hamm, 2013; Shashi, Kottala, \& Singh, 2015). In this section a brief overview of factors that drive consumers' preferences for organic food is provided. A total of 54 papers have been identified (Table A1). According to the Mojet (Köster, 2009) simplified model, all six categories of factors that drive consumers’ preferences toward organic labeled food products were identified in reviewing those papers, but with differing importance in the number of concrete factors (here called sub-factors), as reported in Figure 3. 
Please cite as: Asioli, Daniele; Aschemann-Witzel, Jessica; Caputo, Vincenzina; Vecchio, Riccardo; Annunziata, Azzurra; Næs, Tormod; Varela, Paula. Making sense of the "clean label”, trends: a review of consumer food choice behavior and discussion of industry implications Food Research International, 99, 58-71. https://doi.org/10.1016/j.foodres.2017.07.022

\section{Figure 3 - Essential factors that drive consumers' perceptions and preferences for organic} labeled food products: adapted from Mojet model. Sub-factors were identified from the literature review of 54 papers on “organic”.

$<<$ Please, place here figure 3>>

Considering the socio-cultural factors, a common result from the reviewed studies is that personal norms and ethical values strongly affect consumers' attitudes and buying behavior of organic food products (Aertsens, Verbeke, et al., 2009; Hemmerling et al., 2015; Mørk, Bech-Larsen, Grunert, \& Tsalis, 2017; Shashi et al., 2015). In particular, universalism value, which includes environmental protection and animal welfare, has a positive influence, especially for regular organic consumers rather than occasional ones (Aertsens, Mondelaers, \& van Huylenbroeck, 2009; Mørk et al., 2017; Pino, Peluso, \& Guido, 2012; Thøgersen, de Barcellos, Perin, \& Zhou, 2015). Mørk et al. (2017) found that collectivist values affect attitude toward organic products also in the institutional/public setting. In contrast, Rahnama (2017) found that for Iranian women social and emotional values do not have a significant impact on organic food choices. However, Aertsens et al. (2009) in their literature review stated that egocentric values, such as health and taste, are stronger drivers for organic food purchases rather than altruistic values. In this regard, Husic-Mehmedovic, ArslanagicKalajdzic, Kadic-Maglajlic, \& Vajnberger (2017) found that life equilibrium, in terms of more balanced and caring approach towards one's own life, has a strong, positive effect on perceived intrinsic organic food quality attributes. A second sub-factor is represented by the cultural capital. Indeed, Agovino, Crociata, Quaglione, Sacco, \& Sarra (2017) found that for Italian consumers participation in cultural activities has a positive impact on the purchase organic products. 
Please cite as: Asioli, Daniele; Aschemann-Witzel, Jessica; Caputo, Vincenzina; Vecchio, Riccardo; Annunziata, Azzurra; Næs, Tormod; Varela, Paula. Making sense of the "clean label” trends: a review of consumer food choice behavior and discussion of industry implications Food Research International, 99, 58-71. https://doi.org/10.1016/j.foodres.2017.07.022

A third sub-factor is the level of consumer skepticism and lack of trust towards organic certification that impacts negatively on consumers’ buying behavior (Janssen \& Hamm, 2012a; Nuttavuthisit \& Thøgersen, 2017; Vecchio, Annunziata, Krystallis, \& Pomarici, 2015). The amount of additional information, especially related to the environmental and health effects, represents a third sub-factor linked to an increase of consumers’ willingness to pay (WTP) (Vecchio, Van Loo, \& Annunziata, 2016). Furthermore, general trust in information and trust in media are statistically significant in influencing organic purchases (Dumortier, Evans, Grebitus, \& Martin, 2017).

Education and household composition represents another sub-factor related to the socio-cultural area. Dimitri and Dettmann (2012) and Paul and Rana (2012) found that consumers with higher education levels, as well married households or households with young children, are associated with an increased likelihood of purchasing organic food products.

With reference to the intrinsic product characteristics we identified three sub-factors. The superior product quality in terms of nutritional properties and health promoting effects represents two subfactors that are increasingly gaining relevance for organic food consumption (Aertsens, Verbeke, et al., 2009; Hasimu, Marchesini, \& Canavari, 2017; Hemmerling, Asioli, \& Spiller, 2016; Dumortier, Evans, Grebitus, \& Martin, 2017). Consumers perceive organic food products as healthier and safer (Zagata, 2012; Bryła, 2016; Hasimu et al., 2017; Grzybowska-Brzezinska, Grzywinska-Rapca, Zuchowski, \& Borawski, 2017), as well as an investment in individual health (Kriwy \& Mecking, 2012). Other studies also found that consumers estimated organic food to have better nutritional properties and lower calories than those without the organic label (Lee, Shimizu, Kniffin, \& Wansink, 2013; Pino et al., 2012). Bruschi, Shershneva, Dolgopolova, Canavari, \& Teuber (2015) in their study on Russian consumers, identified positive beliefs about the reduced use of additives 
Please cite as: Asioli, Daniele; Aschemann-Witzel, Jessica; Caputo, Vincenzina; Vecchio, Riccardo; Annunziata, Azzurra; Næs, Tormod; Varela, Paula. Making sense of the "clean label” trends: a review of consumer food choice behavior and discussion of industry implications Food Research International, 99, 58-71. https://doi.org/10.1016/j.foodres.2017.07.022

and food safety as the only factors that significantly affect organic food purchases. Sensory attributes represent the third sub-factor. Taste is an important criterion for organic food purchases and an important predictor for repeated purchases (Asioli et al., 2014; Hemmerling, Asioli, et al., 2016), as well as beliefs about how organic foods taste (Bernard \& Liu, 2017). However, while Hemmerling et al. (2013) found that the presence of an organic label on food products may lead to an enhancement of taste perception, Schuldt \& Hannahan (2013) demonstrated that organic foods were rated as less tasty than conventional ones and Bi et al. (2015) found that consumers' WTP for the sensory attribute was negative for organic juice. On the contrary, Pagliarini, Laureati, \& Gaeta (2013) have shown that the organic and conventional wines differed marginally in the intensity of sensory descriptors and that these differences did not influence consumers liking. Among sensory attributes, flavor and odor were also identified as important in influencing consumers' choice (Asioli et al., 2014). Finally, Hemmerling, Asioli, et al. (2016) found several differences in European consumers' value for the concept of the "Core Organic Taste - COT" which is based on the intrinsic attributes of organic food, those having an impact on sensory food properties.

With reference to the extrinsic product characteristics, we identified four sub-factors. Product sustainability, related to biodiversity and natural resources conservation, as well as lower energy consumption, plays a key role in influencing attitudes and behavior toward organic food products (Shashi et al., 2015). Also animal welfare, fair trade and local origin represent central drivers that explain WTP for organic food (Zanoli et al., 2013). The protection of small farms and rural communities also impacts WTP (De Magistris \& Gracia, 2016; Petrescu, Petrescu-Mag, Burny, \& Azadi, 2017). Labels and certification represent the second sub-factor and are widely acknowledged to be crucial elements for recognition of organic products and to generate trust in its 
Please cite as: Asioli, Daniele; Aschemann-Witzel, Jessica; Caputo, Vincenzina; Vecchio, Riccardo; Annunziata, Azzurra; Næs, Tormod; Varela, Paula. Making sense of the "clean label” trends: a review of consumer food choice behavior and discussion of industry implications Food Research International, 99, 58-71. https://doi.org/10.1016/j.foodres.2017.07.022

credence attributes (Drexler, Fiala, Havlíčková, Potůčková, \& Souček, 2017; Janssen \& Hamm, 2012a, 2012b; Liang, 2016). Samant \& Seo (2016) demonstrate that the presence of organic label affect quality perception of chicken-meat products as a function of consumers' understanding level of the label claims. Nevertheless, some studies revealed a general low awareness about organic certification schemes and logos, especially among European consumers (Van Loo, Diem, Pieniak, \& Verbeke, 2013; Zander, 2014; Zander, Padel, \& Zanoli, 2015).

Other studies have also examined the importance of organic labelling as a sustainability certification (Silva, Bioto, Efraim, \& Queiroz, 2017; Van Loo et al., 2015; Van Loo, Caputo, Nayga, \& Verbeke, 2014; Vecchio \& Annunziata, 2015) showing that, compared with other sustainability labels (e.g. rainforest or carbon foot print) organic is the highest valued and best known label.

The presence of health claims represents the third sub-factor. Consumers tend to consider organic products carrying health claims as healthier (Schleenbecker \& Hamm, 2013), especially occasional organic consumers (Aschemann-Witzel et al., 2013). On the contrary, Gineikiene, Kiudyte, \& Degutis (2017) show that skepticism toward health claims has a negative impact on the perceived healthiness of both organic and conventional products.

Finally, several studies converge on the conclusion that the higher price of organic food products compared to conventional products negatively influences consumers' choice when shopping and generates less repeated purchases (Aschemann-Witzel \& Zielke, 2017; Bravo et al., 2013; Marian, Chrysochou, Krystallis, \& Thøgersen, 2014; Rödiger \& Hamm, 2015). However, it should be noted that Bruschi, Shershneva, Dolgopolova, Canavari, \& Teuber (2015) found that Russian consumers consider the high price of organic food to be a quality indicator, thus the premium price for these products is accepted. 
Please cite as: Asioli, Daniele; Aschemann-Witzel, Jessica; Caputo, Vincenzina; Vecchio, Riccardo; Annunziata, Azzurra; Næs, Tormod; Varela, Paula. Making sense of the "clean label” trends: a review of consumer food choice behavior and discussion of industry implications Food Research International, 99, 58-71. https://doi.org/10.1016/j.foodres.2017.07.022

Considering biological and physiological factors, gender can affect the likelihood to purchase organic food. In particular, women are more likely to buy organic foods than men (Petrescu et al., 2017; Van Loo, Caputo, Nayga, Meullenet, \& Ricke, 2011; Vecchio et al., 2016) as they tend to be the primary food shoppers of the household and they are more aware and sensible of food safety and health issues, compared to men (Aertsens, Verbeke, et al., 2009). In addition, age represents an important factor, as younger consumers are more likely to purchase organic food (Dumortier et al., 2017).

Psychological factors related to modern health worries due to the widespread use of pesticides, antibiotics, and hormones in food processing are strictly related to preferences for organic food products (Hemmerling, Canavari, \& Spiller, 2016).

Finally, among the situational factors the product availability represents a sub-factor that can affect the decision to purchase organic food (Aertsens, Verbeke, et al., 2009). Several papers show that lack of availability and high price represent the main deterrents for buying organic and are the principal determinants of the attitude-behavior gap ${ }^{6}$ for organic consumers (Aschemann-Witzel \& Niebuhr Aagaard, 2014; Aschemann-Witzel \& Zielke, 2017). In addition, Ellison, Duff, Wang, \& White (2016) suggest that retail outlets are a crucial factor with two moderating effects on consumer perception of organic food, the first is on the expected taste and the other on brand trust. Petrescu et al. (2017) found that Romanian consumers perceive farmers’ markets and selfproduction products as the main sources/locations for purchasing uncertified organic food.

\footnotetext{
${ }^{6}$ The attitude-behaviour gap describes a situation where consumers express a positive attitudes towards a product or a favorable buying intention, but their actual behaviour falls short to these due to a number of reasons (Carrington, Neville, \& Whitwell, 2010).
} 
Please cite as: Asioli, Daniele; Aschemann-Witzel, Jessica; Caputo, Vincenzina; Vecchio, Riccardo; Annunziata, Azzurra; Næs, Tormod; Varela, Paula. Making sense of the "clean label” trends: a review of consumer food choice behavior and discussion of industry implications Food Research International, 99, 58-71. https://doi.org/10.1016/j.foodres.2017.07.022

\subsection{Factors that drive consumers' preferences for natural food products}

Nowadays, the attribute "natural” is one of the most-used claims in food marketing, probably because it seems to improve the consumer's quality perception of food products (Coppola \& Verneau, 2010). The growing trend towards naturalness of food products involves both the organic food market, considered to be an important category of natural food, as well as the conventional food industry that in recent years has increased the offer of products reporting natural claims on the label (Hemmerling, Canavari, et al., 2016). Indeed, over the past years the "natural claim” has become one of the leading label claims on new food products launched both in US (Mintel, 2015) and EU markets (Ingredion, 2014). Despite this growing spread of food products claimed to be "natural”, the naturalness of a food product is still a rather vague concept, quite difficult to define properly (Rozin, 2006; Siipi, 2013). Indeed, a universally and formally accepted definition of food naturalness does not exist in the worldwide food market. Rozin (2006) and Rozin et al. (2004) have made an extensive contribution to understanding what is the meaning of "natural" for consumers and what influences consumers' preference for natural food products. The word natural evokes to consumers mostly positive associations, leading to the perception of natural products as tastier, healthier or more environment-friendly. In addition, Franchi (2012) suggested that the term 'natural' is used as a brand representing healthiness, reliability and reassurance in terms of safety and security of food to consumers. Siipi (2013) highlighted how the ambiguous nature of the current uses of the term "naturalness” represents a serious risk for consumers misunderstanding or misbehaving, in particular regarding the connection with its healthiness. The scientific literature often considers the attribute natural as an additional or subordinated aspect of organic food or of non-genetically modified products (non-GMOs) (Hemmerling, Canavari, et al., 2016; Siipi, 2013). 
Please cite as: Asioli, Daniele; Aschemann-Witzel, Jessica; Caputo, Vincenzina; Vecchio, Riccardo; Annunziata, Azzurra; Næs, Tormod; Varela, Paula. Making sense of the "clean label” trends: a review of consumer food choice behavior and discussion of industry implications Food Research International, 99, 58-71. https://doi.org/10.1016/j.foodres.2017.07.022

Consequently, the effects of natural claims on consumers' perceptions and preferences have received substantially less attention in consumer behavior and food marketing literature. A total of 25 articles have been identified (Table A2) and we found six factors of the Mojet model (Köster 2009) applying, as reported in Figure 4.

Considering the socio-cultural factors, Rozin et al. (2004) suggested that both ideational and instrumental reasons ${ }^{7}$ play a central role in affecting consumers’ preferences towards natural food products. However, other literature reports contrasting findings: while Thompson (2011) and Rozin, Fischler, \& Shields-Argelès (2012) proposed that ideological beliefs are more relevant than instrumental beliefs, Li \& Chapman (2012) suggested that preference for natural is mainly influenced by beliefs about natural products in general because they are perceived as healthier and safer than products that are not claimed to be natural. Dubé et al. (2016) found the existence of cross-cultural differences between Americans and Indians in their perceptions and attitudes toward naturally nutritious products, connected with their cultural differences. They conclude that Western consumers (i.e. from the US) are becoming increasingly skeptical to the advances in food and agriculture technologies and more in favor of purchasing natural, organic, and local food products; meanwhile, in developing countries, such as India, the industrialized food supply system is considered a symbol of modernization and better living standards.

Furthermore, knowledge of legal meaning of natural products affects consumers perception of food naturalness. In this regard, Berry, Burton, \& Howlett (2017) showed that providing additional information on the effective meaning of natural label has a positive impact on consumer utility when consumers were not aware of the definition of natural, but not when consumers were

\footnotetext{
${ }^{7}$ Ideational refers to the fact that natural is better because it is morally, aesthetically superior than those which men has influenced while instrumental refers to the fact that natural has superior attributes such as effectiveness, safety and health benefits (Rozin et al., 2004).
} 
Please cite as: Asioli, Daniele; Aschemann-Witzel, Jessica; Caputo, Vincenzina; Vecchio, Riccardo; Annunziata, Azzurra; Næs, Tormod; Varela, Paula. Making sense of the "clean label” trends: a review of consumer food choice behavior and discussion of industry implications Food Research International, 99, 58-71. https://doi.org/10.1016/j.foodres.2017.07.022

informed of the definition of natural. McFadden \& Huffman (2017) found that, for US consumers, adding independent information to the industry food perspectives of natural reduces excess valuations of organics over naturals. Consequently, more balanced and objective understanding of “"natural” foods may be increasingly willing to substitute conventional for "natural” foods.

\section{Figure 4 - Essential factors that drive consumers' perceptions and preferences for natural} food products: adapted from Mojet model. Sub-factors were identified from the literature review of 25 papers on "natural”.

\section{$<<$ Please, place here figure $4>>$}

Among intrinsic characteristics, we identified five sub-factors. Product healthiness is considered the key motivation that influences consumers’ preferences towards natural food products (Binninger, 2015). The term 'natural' is used as a brand representing healthiness, reliability, and reassurance in terms of safety and security of food to consumers (Franchi, 2012). The absence of certain negative intrinsic characteristics (e.g. additives, pollution, human manipulation) represents a second sub-factor (Rozin, Fischler, \& Shields-Argelès, 2012). Sensory attributes, such as pleasure and other aesthetic experiences perception, also represents a third sub-factor suggesting the role of naturalness as a bridge between health and taste (Binninger, 2015; Dubé et al., 2016). In this regards, Dominick et al. (2017) found that respondents perceived products with “all natural” label to have improved taste and improved nutritional value. In addition, they found that responses to "all natural” label vary for different food categories.

However, Hemmerling, Canavari, et al. (2016) suggested the existence of an “attitude-liking gap”, showing that consumers revealed a positive attitude toward natural food, but a negative sensory 
Please cite as: Asioli, Daniele; Aschemann-Witzel, Jessica; Caputo, Vincenzina; Vecchio, Riccardo; Annunziata, Azzurra; Næs, Tormod; Varela, Paula. Making sense of the "clean label” trends: a review of consumer food choice behavior and discussion of industry implications Food Research International, 99, 58-71. https://doi.org/10.1016/j.foodres.2017.07.022

preference for the more natural product. According to Hauser, Jonas, \& Riemann (2011) the presence of fresh and raw ingredients represents a fourth sub-factor. This is because consumers perceive naturalness as a multidimensional concept referring to sustainable, traditional, or organic farming methods, presence of fresh and raw ingredients, and time for preparing and cooking food. The degree of product processing represents a fifth sub-factor. Food processing or manipulation decreases the perception of naturalness (Coppola \& Verneau, 2010; Evans et al., 2010). This confirms the results from Rozin (2006) who stated that "processing alone, without substantial change, can decrease the perception of naturalness.” Abouab and Gomez (2015) showed that food products resulting from handmade production are perceived as more natural than food products resulting from machine-made production and that the level of humanization of the production process positively impacts naturalness perceptions. Furthermore, Aschemann-Witzel \& Grunert, (2017) shows that attitudes towards functional foods were more favourable for food categories that are perceived as natural versus processed.

With reference to extrinsic product characteristics, sustainability is an important sub-factor in influencing the perception of natural food. Binninger (2015) suggested that product sustainability, linked with environmental-friendliness and animal welfare aspects affect consumers' preferences for natural food products. A second sub-factor related to extrinsic product characteristics is packaging. Indeed, Binninger (2015) stated that the naturalness of a food product is perceived by the consumer through the packaging, with both functional signals (labels, logos, or claims) and emotional aspects (colors, shapes, and graphics). Magnier, Schoormans, \& Mugge (2016) also found that perceived naturalness of the product is influenced also by the sustainability of the package that explicitly or implicitly evokes the eco-friendliness of the packaging via its structure, 
Please cite as: Asioli, Daniele; Aschemann-Witzel, Jessica; Caputo, Vincenzina; Vecchio, Riccardo; Annunziata, Azzurra; Næs, Tormod; Varela, Paula. Making sense of the "clean label” trends: a review of consumer food choice behavior and discussion of industry implications Food Research International, 99, 58-71. https://doi.org/10.1016/j.foodres.2017.07.022

graphical or iconographic elements, and informational elements. Label represents a third sub-factor. Amos, Pentina, Hawkins, \& Davis (2014) suggested that food products labeled with natural claims are perceived to be less harmful and healthier, with superior instrumental attributes, and possessing higher nutritional value and lower human contamination. Liu, Hooker, Parasidis, \& Simons (2017) found that the presence of an all-natural FOP label improves consumers' perceptions of product quality and nutritional content. Finally, Li \& Chapman (2012) suggested that perceived risk represents an important instrumental reason for naturalness preference.

Considering biological and physiological factors, women are more receptive to the indication "all natural” on food label (Dominick, Fullerton, Widmar, \& Wang, 2017) and show a greater willingness to pay for organic-“natural” than men (McFadden \& Huffman, 2017). This might be because women are more sensitive than men to risk (Dickson-Spillmann et al., 2011).

Among psychological factors, Devcich et al. (2007) showed that consumers with a higher number of modern health worries (i.e. drug-resistant bacteria or pesticides in food) showed a stronger preference for foods that contain only natural ingredients. In addition, Dickson-Spillmann et al. (2011) found that risk perceptions of chemicals in food were positively correlated with preference for natural food.

Among situational factors, the perception of naturalness depends also on the type of stores, because some of them convey a sense of naturalness, such as traditional markets, leading to more perceived naturalness (Lunardo \& Saintives, 2013). In addition, Liu et al. (2017) found that the additional 
Please cite as: Asioli, Daniele; Aschemann-Witzel, Jessica; Caputo, Vincenzina; Vecchio, Riccardo; Annunziata, Azzurra; Næs, Tormod; Varela, Paula. Making sense of the "clean label” trends: a review of consumer food choice behavior and discussion of industry implications Food Research International, 99, 58-71. https://doi.org/10.1016/j.foodres.2017.07.022

information provided by employed servers at the point of purchase impacts consumers' perceptions of quality and nutritional content of all-natural labelled products.

\subsection{Factors affecting consumers' perceptions and preferences for food 'free from artificial additives/ingredients”}

Food additives are substances that added to food products are able to improve their intrinsic attributes due to their technological and sensory functions (i.e. to increase shelf life by reducing their perishability, improve taste, restore colours, etc.). This enables the food industry to produce food products that meet the more complex and segmented consumer desires (Carocho, Morales, \& Ferreira, 2015; Emerton \& Choi, 2008; Saltmarsh, 2013). Different definitions of food additives are provided by Codex Alimentarius, the Food and Drug Administration (FDA) and the European Food Safety Authority (EFSA) (for details see Carocho et al., 2015). Food additives can be categorized based on two different characteristics: their origin and function. In terms of origin there are artificial and natural additives. In terms of function six categories can be identified: preservatives, nutritional additives, colouring agents, flavouring agents, texturing agents and miscellaneous agents (Carocho, Barreiro, Morales, \& Ferreira, 2014).

Despite the mentioned advantages, the relationship between consumers and food additives has always been problematic (Carocho et al., 2015). Indeed, since the late 1970s consumers started to think that artificial additives/ingredients might be dangerous for health, and that it would be preferable to reduce or avoid their use in food products (Brockman \& Beeren, 2011). For example, the cases of aspartame, colours, and monosodium glutamate have contributed to rising public concerns about how addition of these substances to food products might have bad health effects 
Please cite as: Asioli, Daniele; Aschemann-Witzel, Jessica; Caputo, Vincenzina; Vecchio, Riccardo; Annunziata, Azzurra; Næs, Tormod; Varela, Paula. Making sense of the "clean label” trends: a review of consumer food choice behavior and discussion of industry implications Food Research International, 99, 58-71. https://doi.org/10.1016/j.foodres.2017.07.022

(Carocho et al., 2014; Lofstedt, 2008, 2009; Mosby, 2009). Also the European terminology used to identify additives on food labels (i.e. E-numbers) are perceived with suspicion by consumers due to their unfamiliar names (Osborne, 2015). Generally, consumers will choose food without additives, but if these are not available, then consumes will choose food containing natural additives over the artificial ones (Carocho et al., 2014). Thus, a key element that drives some consumers to prefer food products without artificial additives/ingredients is related to the additives' origin, either natural or artificial. Even if there is no clear difference between the origin of food additives in both the scientific literature and public legislation, previous research suggests that consumers are able to differentiate them (Stern, Haas, \& Meixner, 2009; Tarnavöglyi, 2003).

A total of 16 papers about consumers’ perceptions and preferences for “free-from artificial additives/ingredients” foods have been identified (Table A3). Five out of six factors of the Mojet model (Köster 2009) have been identified, as reported in Figure 5.

Figure 5 -Essential factors that drive consumers' perceptions and preferences for food “free from artificial additives/ingredients”: adapted from Mojet model. Sub-factors were identified from the literature review of 16 papers on “free from artificial additives/ingredients". $<<$ Please, place here figure 5>>

Among the socio-cultural factors we identified five sub-factors. The first sub-factor is related to the fact that consumers who are more sensitive to negative information sources, gained by watching and hearing media coverage (i.e. Internet) or family and friends discussions, feel more anxiety about food additives and might tend easily to their rejection (Tanaka, Kitayama, Arai, \& 
Please cite as: Asioli, Daniele; Aschemann-Witzel, Jessica; Caputo, Vincenzina; Vecchio, Riccardo; Annunziata, Azzurra; Næs, Tormod; Varela, Paula. Making sense of the "clean label” trends: a review of consumer food choice behavior and discussion of industry implications Food Research International, 99, 58-71. https://doi.org/10.1016/j.foodres.2017.07.022

Matsushima, 2015; Wansink, Tal, \& Brumberg, 2014). In addition, the role of nutrition teachers and members of non-governmental organization can cause negative consumers perception of food additives (Kang et al., 2017). This is linked to social acceptance. A second sub-factor is related to education. Wu et al. (2013) stated that consumers with lower levels of education tend to be more likely to purchase food products with additives that follow governments' standards, because they trust governments more, than those who have higher education levels. A third sub-factor is the lack of awareness and trust in food regulation which is linked to the acceptance of food additives (Bearth et al. 2014). A fourth sub-factor is related to the ethical, cultural, and ascetic concerns that consumers might have about artificial additives/ingredients (Haen, 2014). A fifth sub-factor is the consumers’ self-reported knowledge (Szucs, Szabo, \& Bana, 2014).

The intrinsic product characteristics are also important drivers. We identified three sub-factors. The first sub-factor is related to the type of additive that might affect consumers' perceptions differently (i.e. sweeteners are perceived as slightly more acceptable than colours) (Bearth et al., 2014). A second sub-factor is the type of food associated with the ingredient (i.e. ingredients associated with unhealthy food are less accepted by consumers) (Wansink et al. 2014). Finally, consumers that prefer natural food products also prefer to avoid artificial additives/ingredients (Bearth et al., 2014).

Among the extrinsic product characteristics we identified five sub-factors. First, is the knowledge of the food product which includes the additive affects the acceptance of a food additive itself (Bastian, Saltman, Johnson, \& Wilkinson, 2015; Kubota, Sawano, \& Kono, 2017). The second is the lack of information about food additives also drives consumers into reject them because it was 
Please cite as: Asioli, Daniele; Aschemann-Witzel, Jessica; Caputo, Vincenzina; Vecchio, Riccardo; Annunziata, Azzurra; Næs, Tormod; Varela, Paula. Making sense of the "clean label” trends: a review of consumer food choice behavior and discussion of industry implications Food Research International, 99, 58-71. https://doi.org/10.1016/j.foodres.2017.07.022

considered insufficient (Kubota et al., 2017; Shim et al., 2011). A third sub-factor is related to the risk perception/attention to media which has a strong influence on consumers' acceptance of food additives (Chen, 2017). A fourth sub-factor is related to the type of symbolic information reported on the label: using E-numbers instead of specify food additives as chemicals are perceived less natural by consumers (Siegrist \& Sütterlin, 2017). Finally, the costs/price of food products affect consumers' intent to purchase. Consumers that are more sensitive to price (men, younger, and low income consumers) were more willing to accept additives due to their lower costs (Wu et al., 2013).

Among psychological factors, two sub-factors can be identified. One is related to the health concern about the possible bad effects that artificial additives/ingredients can cause to human health (Chen, 2017; Shim et al., 2011; Szucs et al., 2014; Varela \& Fiszman, 2013), while the other is the familiarity that consumers have with a food additive plays a key role in their acceptance/rejection, since consumers are scared about names that they have not used (i.e. high-fructose corn syrup) (Varela \& Fiszman, 2013; Wansink et al., 2014).

Finally, among the biological and physiological factors, two sub-factors related to socio demographic characteristics, gender (i.e. women perceive more risk than men) (Bearth et al., 2014; Dickson-Spillmann et al., 2011) and age (i.e. young people are less concerned than older people about food safety) (De Jonge, Van Trijp, Jan Renes, \& Frewer, 2007; Lupton, 2005) affect consumers' perceptions and preferences for avoiding food products with artificial additives/ingredients. 
Please cite as: Asioli, Daniele; Aschemann-Witzel, Jessica; Caputo, Vincenzina; Vecchio, Riccardo; Annunziata, Azzurra; Næs, Tormod; Varela, Paula. Making sense of the "clean label” trends: a review of consumer food choice behavior and discussion of industry implications Food Research International, 99, 58-71. https://doi.org/10.1016/j.foodres.2017.07.022

\section{DISCUSSION}

\subsection{Clean label definition and consumer understanding}

Across the three categories of food products pertaining to the clean label trend - organic, 'natural', and 'free from' artificial additives/ingredients - we found all the six categories of factors represented of the Mojet model (Köster, 2009), such as intrinsic and extrinsic product characteristics, biological and physiological, as well as psychological, situational and socio-cultural factors. Thus, as a first point, we can conclude that a broad diversity of drivers has been found to influence the clean label trend, according to empirical consumer studies of the past six years. As a second observation, we can conclude on a number of similarities across the three product categories: it becomes apparent that the greater majority of studies identify crucial factors among intrinsic or extrinsic product characteristics, as well as among socio-cultural factors. Thus, these factors are either of greater importance, or have been given more focus in empirical research. Studies for all three categories underline the importance of 'health' as a motivation via various forms of factors, as e.g. healthiness of the product, health claims on the package, or health concerns of the consumer. In addition, the factor of high prices and costs of purchase are identified for all food categories. However, there are also differences between the factors emerging as relevant when comparing the categories, concluded as a third point: according to the studies reviewed, intrinsic product characteristics were found more often identified as factors impacting consumer behaviour for natural and 'free from' food than for organic. Interestingly, though, sensory characteristics had not been identified in any study on 'free from' food so far, but instead, biological and physical are factors more prominent for 'free from' than for the other two categories. In addition, 'sustainability' was found as a motive impacting consumer behaviour and choice for organic and natural food, but not for 'free from'. 
Please cite as: Asioli, Daniele; Aschemann-Witzel, Jessica; Caputo, Vincenzina; Vecchio, Riccardo; Annunziata, Azzurra; Næs, Tormod; Varela, Paula. Making sense of the "clean label” trends: a review of consumer food choice behavior and discussion of industry implications Food Research International, 99, 58-71. https://doi.org/10.1016/j.foodres.2017.07.022

Overall, we conclude that while various factors across the whole range of drivers explain consumer preference for clean label, research so far points in particular to intrinsic and extrinsic product characteristics and the socio-cultural factors determining individual consumer characteristics, but above all to the issue of 'health'. In addition, the literature review finds that the structure of factors explaining ‘free from' differs in several points from organic and natural ${ }^{8}$, indicating that this category is to be regarded as different and apart from the latter two. It should be underlined, though, that the smaller range of research studies identified for 'free from' might explain part of the differences. In addition, it must be cautioned that research studies might point to certain factors, but that other factors might be underlying the result as well, but have not been measured.

Considering these findings of the literature review on the background of the consumer behaviour theory introduced as potentially relevant for the topic of clean label and consumer perception, it is interesting to note that the different role of 'free from' food appears in line with the distinction that theory suggests. Regarding dual processing (Kitchen et al., 2014; Petty et al., 1983), it can be said that cues such as the fact that the product is certified organic or claims and product characteristics hinting at naturalness might be more likely processed peripherally, leading to broad associations about intrinsic and extrinsic product characteristics. These are more explained by consumer beliefs than by actual knowledge, given they are credence quality characteristics in its majority. While 'free from' might also be a cue, it is much easier for consumers to assess the claim and, as a consequence of the BOP information, centrally process the information, leading to more detailed product characteristics mentioned. With regard to approach and avoidance information (Higgins,

\footnotetext{
${ }^{8}$ Previous works underline that often consumers consider organic as category of natural products (Hemmerling, Asioli, et al., 2016).
} 
Please cite as: Asioli, Daniele; Aschemann-Witzel, Jessica; Caputo, Vincenzina; Vecchio, Riccardo; Annunziata, Azzurra; Næs, Tormod; Varela, Paula. Making sense of the "clean label” trends: a review of consumer food choice behavior and discussion of industry implications Food Research International, 99, 58-71. https://doi.org/10.1016/j.foodres.2017.07.022

2005), we have argued and shown that avoidance underlies all three clean label food categories. However, 'free from' food is a more obvious and straightforward trend of avoiding 'something', and this fact appears to be mirrored in the findings setting the category apart.

Considering the findings and the definition introduced in this paper, the importance of a broad range of factors influencing the clean label trend as well as the similarities in factors across all three categories support that they are joined in under one common definition. Both 'assumption/ inference’ as well as ‘inspection’ appear relevant, given both intrinsic and extrinsic product characteristics are important factors explaining consumer choice, as well as individual characteristics as impacted by the socio-cultural factors. However, the category of 'free from' might differ from organic and natural, and it appears more likely that this category is perceived more via inspection and thus pertaining to clean label in the strict sense.

\subsection{Implications for food manufacturers and policy makers}

A number of implications for food manufacturers can be derived from the findings. Firstly, food manufacturers should expect that a diversity of factors impact the clean label trend, and thus need to be prepared to take the diversity of these drivers into account in developing new products (Frewer et al., 2011; Van Kleef, Van Trijp, \& Luning, 2005) as well as in the communication and positioning of the products in the market for clean label food. In particular, intrinsic and extrinsic product characteristics and socio-cultural factors influence the trend, while less is found for or known for the remaining factors. Secondly and not surprisingly, health emerges as a crucial issue that is mirrored in a number of factors according to consumer research, thus, the clean label food product trend should continue to be understood as essentially driven by health motivations and 
Please cite as: Asioli, Daniele; Aschemann-Witzel, Jessica; Caputo, Vincenzina; Vecchio, Riccardo; Annunziata, Azzurra; Næs, Tormod; Varela, Paula. Making sense of the "clean label” trends: a review of consumer food choice behavior and discussion of industry implications Food Research International, 99, 58-71. https://doi.org/10.1016/j.foodres.2017.07.022

concerns. In consequence, product development and communication should prioritize this issue, given consumers demand such health-related aspects in ingredients that influence the clean label perception of a food (as e.g. colorants, Martins, Roriz, Morales, Barros, \& Ferreira (2016). Thirdly, the finding that 'free from' foods appear to be needed to be seen as apart from organic and natural food implies that food manufacturers should have potential differences in the target group in mind, depending on which category of clean label food they deal with. 'Free from' food products appear to show a clearer distinction via biological and physiological factors, consumers might give less importance to sensory characteristics, while even more to health and not necessarily much to sustainability as a motive. However, further research is needed to explore these differences more in detail.

For policy makers interacting with food processors, it appears important to work towards a more homogenous understanding and application of the term of clean label. A uniform definition or even regulation might establish a level playing field that would support the trend towards natural and 'free from' food in a similar way as the regulation and certification has supported the market for organic food in the past. Health and health worries are a major driver, which entails that policy makers need to consider how to ensure that consumers are not misled in any way, and in fact choose healthy when using cues referring to clean label as a guidance in their choices. In particular, policy makers should aim to support measures that allow prices for clean label to decrease, so that all groups of consumers can afford such products, given price appears to be an issue across all categories. Consumer understanding and acceptance of technologies yet appearing unfamiliar, but providing consumer benefits needs to be understood and tackled (Rollin, Kennedy, \& Wills, 2011). 
Please cite as: Asioli, Daniele; Aschemann-Witzel, Jessica; Caputo, Vincenzina; Vecchio, Riccardo; Annunziata, Azzurra; Næs, Tormod; Varela, Paula. Making sense of the "clean label” trends: a review of consumer food choice behavior and discussion of industry implications Food Research International, 99, 58-71. https://doi.org/10.1016/j.foodres.2017.07.022

Overall, the clean label trend emerges driven by factors such as modern health worries and concerns related to modern and high technology processing, perceived risk and skepticism towards certain ingredients, processing techniques, but also lack of trust in regulations. It appears that certain advantages of food processing for health and sustainability might likely be overlooked by consumers (Augustin et al., 2016). Thus, both policy makers and food processers might need to engage in consumer education about certain ingredients that might be misconceived by consumers, in a targeted way that corresponds to consumer's involvement level and processing of information. In addition, they need to regain greater consumer trust in regulations and food production processes (Frewer et al., 2011) in response to the factors underlying the clean label trend.

\subsection{Future research directions}

This review has brought forth many questions in need of further investigations for the underresearched category of clean label food products. For instance, future studies should further establish which factors drive consumer choices for certain types (i.e. sweeteners, colourants, etc.) of 'free from' food products, and how preferences for such food products differ across diverse consumer groups. Findings from such studies would help food manufacturers understand the target market and how these consumers differ from organic and natural food consumers.

Furthermore, given most studies in the literature review are from developed countries (e.g., European countries, among others) but there might be cultural differences that impact consumers' perceptions and preferences in emerging and developing countries, broadening research towards other regions of the world would be beneficial. 
Please cite as: Asioli, Daniele; Aschemann-Witzel, Jessica; Caputo, Vincenzina; Vecchio, Riccardo; Annunziata, Azzurra; Næs, Tormod; Varela, Paula. Making sense of the "clean label” trends: a review of consumer food choice behavior and discussion of industry implications Food Research International, 99, 58-71. https://doi.org/10.1016/j.foodres.2017.07.022

Moreover, this paper focuses solely on three categories of clean label food products. Some research focus should therefore be placed on the other product categories available in food markets such as gluten-free products, short-list ingredients among others. Since recent evidence suggests that the values consumers attach to a food product embedding a certain quality characteristic depends on the presence of other characteristics depicting it (Caputo, Scarpa, \& Nayga, 2017; Gao \& Schroeder, 2009) more research is needed to investigate such dependence that might also exist in the context of clean label food products that in turn will improve the knowledge around this topic. However, while several studies have assessed consumers' preferences and WTP for organic and/or natural products, there is a lack of research that investigate preferences and WTP for food products 'free from' artificial additives/ingredients.

Furthermore, research investigating how consumers value multiple food attributes claimed as “clean” simultaneously is needed. Results from these studies might help food companies to formulate adequate product development practices, pricing and marketing strategies as well as policy makers to determine the costs and benefits of various food labeling policies.

Finally, further research should be undertaken to investigate the behavioural reasons driving consumer decision making processes for ‘free from’ food products. For instance, future research could employ the structural equation modelling (SEM) approach to investigate the strength of the relationships existing among the factors identified in this paper 'free from' food products (and also for organic and natural products) to better understand how they concretely contribute to consumer choice decisions. Another possible area of future research would be to establish whether the inclusion of various psychological factors (e.g. risk preferences, time preferences, personality, 
Please cite as: Asioli, Daniele; Aschemann-Witzel, Jessica; Caputo, Vincenzina; Vecchio, Riccardo; Annunziata, Azzurra; Næs, Tormod; Varela, Paula. Making sense of the "clean label” trends: a review of consumer food choice behavior and discussion of industry implications Food Research International, 99, 58-71. https://doi.org/10.1016/j.foodres.2017.07.022

among others) into economic models of consumer demand could improve their predictive power, and thus help to better understand consumer decision making processes for the different categories of clean label products. Finally, consumer valuation for the various ‘free from' food products are driven by the presence of both intrinsic and extrinsic product characteristics. Thus, further experimental investigations are needed to explore how consumers value sensory aspects related to 'free from' food products as compared to those characterizing conventional food products by for example using different consumer valuation methods as proposed by Asioli et al. (2017).

\section{ACKNOWLEDGEMENTS}

Financial support from the European Commission through the Marie Curie Actions Intra European Fellowship (IEF), call FP/-PEOPLE-I2012-IEF - project title “'Innovative Methodologies for New Food Product Development: combining Sensory Science and Experimental Economics NEFOMET’. Nofima's authors also would like to thank the support of the Norwegian Foundation for Research Levy on Agricultural Products through the research program "FoodSMaCK, Spectroscopy, Modelling and Consumer Knowledge” (2017-2020). Special thanks also to the editor Anderson de Souza Sant'Ana for suggesting the authors the writing of this review paper.

\section{AUTHOR CONTRIBUTIONS}

The authors' contributions were as follows: Daniele Asioli was the responsible for the overall manuscript, contributed to the introduction, design and literature review. Jessica Aschemann-Witzel contributed to the consumer behaviour theory, clean label definition and discussion as well as the critical review of the manuscript. Vincenzina Caputo contributed to the discussion and the critical review of the manuscript. Azzurra Annunziata and Riccardo Vecchio contributed to the literature 
Please cite as: Asioli, Daniele; Aschemann-Witzel, Jessica; Caputo, Vincenzina; Vecchio, Riccardo; Annunziata, Azzurra; Næs, Tormod; Varela, Paula. Making sense of the "clean label” trends: a review of consumer food choice behavior and discussion of industry implications Food Research International, 99, 58-71. https://doi.org/10.1016/j.foodres.2017.07.022

review and the critical review of the manuscript. Tormod Naes contributed to the critical review of the manuscript. Finally, Paula Varela contributed to the design of the study and critical review of the manuscript. 
Please cite as: Asioli, Daniele; Aschemann-Witzel, Jessica; Caputo, Vincenzina; Vecchio, Riccardo; Annunziata, Azzurra; Næs, Tormod; Varela, Paula. Making sense of the "clean label” trends: a review of consumer food choice behavior and discussion of industry implications Food Research International, 99, 58-71. https://doi.org/10.1016/j.foodres.2017.07.022

\section{REFERENCES}

Aaker, J. L., \& Lee, A. Y. (2001). “I” Seek Pleasures and “We” Avoid Pains: The Role of SelfRegulatory Goals in Information Processing and Persuasion. Journal of Consumer Research, 28(1), 33-49.

Abouab, N., \& Gomez, P. (2015). Human contact imagined during the production process increases food naturalness perceptions. Appetite, 91, 273-277.

Adams, D. C., \& Salois, M. J. (2010). Local versus organic: A turn in consumer preferences and willingness-to-pay. Renewable Agriculture and Food Systems, 25(4), 331-341.

Aertsens, J., Mondelaers, K., \& van Huylenbroeck, G. (2009). Differences in retail strategies on the emerging organic market. British Food Journal, 111(2), 138-154.

Aertsens, J., Verbeke, W., Mondelaers, K., \& van Huylenbroeck, G. (2009). Personal determinants of organic food consumption: a review. British Food Journal, 111(10), 1140-1167.

Agovino, M., Crociata, A., Quaglione, D., Sacco, P., \& Sarra, A. (2017). Good Taste Tastes Good. Cultural Capital as a Determinant of Organic Food Purchase by Italian Consumers: Evidence and Policy Implications. Ecological Economics, 141, 66-75.

Aktar, M., Sengupta, D., \& Chowdhury, A. (2009). Impact of pesticides use in agriculture: their benefits and hazards. Interdisciplinary Toxicology, 1(2), 1-12.

Amos, C., Pentina, I., Hawkins, T. G., \& Davis, N. (2014). “Natural” labeling and consumers’ sentimental pastoral notion. Journal of Product \& Brand Management, 23(4/5), 268-281.

Aschemann-Witzel, J., \& Grunert, K. G. (2017). Attitude towards resveratrol as a healthy botanical ingredient: The role of naturalness of product and message. Food Quality and Preference, 57, 126-135. 
Please cite as: Asioli, Daniele; Aschemann-Witzel, Jessica; Caputo, Vincenzina; Vecchio, Riccardo; Annunziata, Azzurra; Næs, Tormod; Varela, Paula. Making sense of the "clean label” trends: a review of consumer food choice behavior and discussion of industry implications Food Research International, 99, 58-71. https://doi.org/10.1016/j.foodres.2017.07.022

Aschemann-Witzel, J., Maroscheck, N., \& Hamm, U. (2013). Are organic consumers preferring or avoiding foods with nutrition and health claims? Food Quality and Preference, 30(1), 68-76.

Aschemann-Witzel, J., \& Niebuhr Aagaard, E. M. (2014). Elaborating on the attitude-behaviour gap regarding organic products: young Danish consumers and in-store food choice. International Journal of Consumer Studies, 38(5), 550-558.

Aschemann-Witzel, J., \& Zielke, S. (2017). Can’t Buy Me Green? A Review of Consumer Perceptions of and Behavior Toward the Price of Organic Food. Journal of Consumer Affairs, 51(1), 211-251.

Aschemann, J., Hamm, U., Naspetti, S., \& Zanoli, R. (2007). The organic market. In W. Lockeretz (Ed.), Organic farming - an international history. (pp. 123-151). Oxfordshire/UK and Cambridge/MA/USA: CAB International.

Asioli, D., Canavari, M., Pignatti, E., Obermowe, T., Sidali, K. L., Vogt, C., \& Spiller, A. (2014). Sensory Experiences and Expectations of Italian and German Organic Consumers. Journal of International Food \& Agribusiness Marketing, 26(1), 13-27.

Asioli, D., Varela, P., Hersleth, M., Almli, V. L., Olsen, N. V., \& Næs, T. (2017). A discussion of recent methodologies for combining sensory and extrinsic product properties in consumer studies. Food Quality and Preference, 56, Part B, 266-273.

Augustin, M. A., Riley, M., Stockmann, R., Bennett, L., Kahl, A., Lockett, T., ... Cobiac, L. (2016). Role of food processing in food and nutrition security. Trends in Food Science \& Technology, 56, 115-125.

Bánáti, D. (2011). Consumer response to food scandals and scares. Trends in Food Science \& Technology, 22(2-3), 56-60. 
Please cite as: Asioli, Daniele; Aschemann-Witzel, Jessica; Caputo, Vincenzina; Vecchio, Riccardo; Annunziata, Azzurra; Næs, Tormod; Varela, Paula. Making sense of the "clean label” trends: a review of consumer food choice behavior and discussion of industry implications Food Research International, 99, 58-71. https://doi.org/10.1016/j.foodres.2017.07.022

Bastian, S., Saltman, Y., Johnson, T., \& Wilkinson, K. (2015). Australian wine consumers’ acceptance of and attitudes toward the use of additives in wine and food production. International Journal of Wine Research, Volume 7, 83.

Bearth, A., Cousin, M. E., \& Siegrist, M. (2014). The consumer's perception of artificial food additives: Influences on acceptance, risk and benefit perceptions. Food Quality and Preference, 38:14-23.

Beck, U. (1992). Risk society: towards a new modernity. London, UK: Sage Publications Ltd.

Beharrell, B., \& Denison, T. J. (1995). Involvement in a routine food shopping context. British Food Journal, 97(4), 24-29.

Bernard, J. C., \& Liu, Y. (2017). Are beliefs stronger than taste? A field experiment on organic and local apples. Food Quality and Preference, 61, 55-62.

Berry, C., Burton, S., \& Howlett, E. (2017). It’s only natural: the mediating impact of consumers’ attribute inferences on the relationships between product claims, perceived product healthfulness, and purchase intentions. Journal of the Academy of Marketing Science.

Bi, X., Gao, Z., House, L. A., \& Hausmann, D. S. (2015). Tradeoffs between sensory attributes and organic labels: the case of orange juice. International Journal of Consumer Studies, 39(2), $162-171$.

Binninger, A.-S. (2015). Perception of Naturalness of Food Packaging and Its Role in Consumer Product Evaluation. Journal of Food Products Marketing, 1-17.

Bravo, C. P., Cordts, A., Schulze, B., \& Spiller, A. (2013). Assessing determinants of organic food consumption using data from the German National Nutrition Survey $\{$ II $\}$. Food Quality and Preference, 28(1), 60-70. 
Please cite as: Asioli, Daniele; Aschemann-Witzel, Jessica; Caputo, Vincenzina; Vecchio, Riccardo; Annunziata, Azzurra; Næs, Tormod; Varela, Paula. Making sense of the "clean label” trends: a review of consumer food choice behavior and discussion of industry implications Food Research International, 99, 58-71. https://doi.org/10.1016/j.foodres.2017.07.022

Brockman, C., \& Beeren, C. J. M. (2011). Additives in Dairy Foods | Consumer Perceptions of Additives in Dairy Products. In J. W. Fuquay (Ed.), Encyclopedia of Dairy Sciences (Second Edition) (2nd ed., pp. 41-48). San Diego: Academic Press.

Brunsø, K., \& Grunert, K. G. (1995). Development and testing of a cross-culturally valid instrument: Food-related lifestyle. Advances in Consumer Research, 22, 475-480.

Bruschi, V., Shershneva, K., Dolgopolova, I., Canavari, M., \& Teuber, R. (2015). Consumer Perception of Organic Food in Emerging Markets: Evidence from Saint Petersburg, Russia. Agribusiness, 31(3), 414-432.

Bryła, P. (2016). Organic food consumption in Poland: Motives and barriers. Appetite, 105, 737746.

Busken, D. F. (2013). Cleaning It Up—What Is a Clean Label Ingredient? Cereals Foods Worlds, 60(2), 112-113.

Caputo, V., Nayga, R. M., \& Scarpa, R. (2013). Food miles or carbon emissions? Exploring labelling preference for food transport footprint with a stated choice study. Australian Journal of Agricultural and Resource Economics, 57(4), 465-482.

Caputo, V., Scarpa, R., \& Nayga, R. M. J. (2017). Cue versus independent food attributes: the effect of adding attributes in choice experiments. European Review of Agricultural Economics, 44(2), 211-230.

Carocho, M., Barreiro, M. F., Morales, P., \& Ferreira, I. C. F. R. (2014). Adding molecules to food, pros and cons: A review on synthetic and natural food additives. Comprehensive Reviews in Food Science and Food Safety, 13(4):377-399.

Carocho, M., Morales, P., \& Ferreira, I. C. F. R. (2015). Natural food additives: Quo vadis? Trends 
Please cite as: Asioli, Daniele; Aschemann-Witzel, Jessica; Caputo, Vincenzina; Vecchio, Riccardo; Annunziata, Azzurra; Næs, Tormod; Varela, Paula. Making sense of the "clean label” trends: a review of consumer food choice behavior and discussion of industry implications Food Research International, 99, 58-71. https://doi.org/10.1016/j.foodres.2017.07.022

in Food Science \& Technology, 45, 284-295.

Carrington, M. J., Neville, B. A., \& Whitwell, G. J. (2010). Why Ethical Consumers Don’t Walk Their Talk: Towards a Framework for Understanding the Gap Between the Ethical Purchase Intentions and Actual Buying Behaviour of Ethically Minded Consumers. Journal of Business Ethics, 97(1), 139-158.

Chalamon, I., \& Nabec, L. (2016). Why Do We Read On-Pack Nutrition Information so Differently? A Typology of Reading Heuristics Based on Food Consumption Goals. Journal of Consumer Affairs, 50(2), 403-429.

Chen, M.-F. (2017). Modeling an extended theory of planned behavior model to predict intention to take precautions to avoid consuming food with additives. Food Quality and Preference, 58, 24-33.

Cheung, T. T. L., Junghans, A. F., Dijksterhuis, G. B., Kroese, F., Johansson, P., Hall, L., \& Ridder, D. T. D. De. (2016). Consumers' choice-blindness to ingredient information. Appetite, 106:212.

Coppola, A., \& Verneau, F. (2010). Naturalness and Consumer Choices: The Case of Microfiltered Milk. In Proceedings of the 4th International European Forum on System Dynamics and Innovation in Food Networks (pp. 187-201). Innsbruck, Austria.

Das, G. (2015). Retail shopping behaviour: understanding the role of regulatory focus theory. The International Review of Retail, Distribution and Consumer Research, 25(4), 431-445.

de Boer, J., \& Schösler, H. (2016). Food and value motivation: Linking consumer affinities to different types of food products. Appetite, 103, 95-104.

De Jonge, J., Van Trijp, H., Jan Renes, R., \& Frewer, L. (2007). Understanding Consumer 
Please cite as: Asioli, Daniele; Aschemann-Witzel, Jessica; Caputo, Vincenzina; Vecchio, Riccardo; Annunziata, Azzurra; Næs, Tormod; Varela, Paula. Making sense of the "clean label”, trends: a review of consumer food choice behavior and discussion of industry implications Food Research International, 99, 58-71. https://doi.org/10.1016/j.foodres.2017.07.022

Confidence in the Safety of Food: Its Two-Dimensional Structure and Determinants. Risk Analysis, 27(3), 729-740.

De Magistris, T., \& Gracia, A. (2016). Consumers’ willingness-to-pay for sustainable food products: the case of organically and locally grown almonds in Spain. Journal of Cleaner Production, 118, 97-104.

Devcich, D. A., Pedersen, I. K., \& Petrie, K. J. (2007). You eat what you are: Modern health worries and the acceptance of natural and synthetic additives in functional foods. Appetite, 48(3), 333-337.

Dholakia, U. M., Kahn, B. E., Reeves, R., Rindfleisch, A., Stewart, D., \& Taylor, E. (2010). Consumer Behavior in a Multichannel, Multimedia Retailing Environment. Journal of Interactive Marketing, 24(2), 86-95.

Dickson-Spillmann, M., Siegrist, M., \& Keller, C. (2011). Attitudes toward chemicals are associated with preference for natural food. Food Quality and Preference, 22(1), 149-156.

Dimitri, C., \& Dettmann, R. L. (2012). Organic food consumers: what do we really know about them? British Food Journal, 114(8), 1157-1183.

Dominick, S. R., Fullerton, C., Widmar, N. J. O., \& Wang, H. (2017). Consumer Associations with the “All Natural” Food Label. Journal of Food Products Marketing, 1-14.

Draper, A. K., Adamson, A. J., Clegg, S., Malam, S., Rigg, M., \& Duncan, S. (2013). Front-of-pack nutrition labelling: are multiple formats a problem for consumers? The European Journal of Public Health, 23(3), 517-521.

Drexler, D., Fiala, J., Havlíčková, A., Potůčková, A., \& Souček, M. (2017). The Effect of Organic Food Labels on Consumer Attention. Journal of Food Products Marketing, 1-15. 
Please cite as: Asioli, Daniele; Aschemann-Witzel, Jessica; Caputo, Vincenzina; Vecchio, Riccardo; Annunziata, Azzurra; Næs, Tormod; Varela, Paula. Making sense of the "clean label” trends: a review of consumer food choice behavior and discussion of industry implications Food Research International, 99, 58-71. https://doi.org/10.1016/j.foodres.2017.07.022

Dubé, L., Fatemi, H., Lu, J., \& Hertzer, C. (2016). The Healthier the Tastier? USA-India Comparison Studies on Consumer Perception of a Nutritious Agricultural Product at Different Food Processing Levels. Frontiers in Public Health, 4(6), 1-11.

Dumortier, J., Evans, K. S., Grebitus, C., \& Martin, P. A. (2017). The Influence of Trust and Attitudes on the Purchase Frequency of Organic Produce. Journal of International Food \& Agribusiness Marketing, 29(1), 46-69.

Edwards, A. (2013). Natural \& Clean Label Trends June 2013. Ingredion Incorporated.

Eertmans, A., Victoir, A., Vansant, G., \& den Bergh, O. Van. (2005). Food-related personality traits, food choice motives and food intake: Mediator and moderator relationships. Food Quality and Preference, 16(8), 714-726.

Ellison, B., Duff, B. R. L., Wang, Z., \& White, T. B. (2016). Putting the organic label in context: Examining the interactions between the organic label, product type, and retail outlet. Food Quality and Preference, 49, 140-150.

Emerton, V., \& Choi, E. (2008). Essential Guide to Food Additives. (Leatherhead Food International, Ed.). The Royal Society of Chemistry.

Euromonitor International. (2016). Report extract: lifestyle 2016: new survey insights and system refresher.

Evans, J. S. B. T. (2003). In two minds: dual-process accounts of reasoning. Trends in Cognitive Sciences, 7(10), 454-459.

Evans, de Challemaison, B., \& Cox, D. N. (2010). Consumers' ratings of the natural and unnatural qualities of foods. Appetite, 54(3), 557-563.

Fellows, P. (2004). Processed foods for improved livelihoods. FAO Diversification Booklet (FAO). 
Please cite as: Asioli, Daniele; Aschemann-Witzel, Jessica; Caputo, Vincenzina; Vecchio, Riccardo; Annunziata, Azzurra; Næs, Tormod; Varela, Paula. Making sense of the "clean label” trends: a review of consumer food choice behavior and discussion of industry implications Food Research International, 99, 58-71. https://doi.org/10.1016/j.foodres.2017.07.022

FIBL. (2017). The World of Organic Agriculture. (H. Willer \& J. Lernoud, Eds.). Frick, Switzerland.

Franchi, M. (2012). Food choice: beyond the chemical content. International Journal of Food Sciences and Nutrition, 63(sup1), 17-28.

Frewer, L. J., Bergmann, K., Brennan, M., Lion, R., Meertens, R., Rowe, G., ... Vereijken, C. (2011). Consumer response to novel agri-food technologies: Implications for predicting consumer acceptance of emerging food technologies. Trends in Food Science \& Technology, 22(8), 442-456.

Frewer, L. J., \& van Trijp, H. (2007). Understanding Consumers of Food Products. Cambridge, UK: Woodhead Publishing, CRC Press.

Gao, Z., \& Schroeder, T. C. (2009). Effects of Label Information on Consumer Willingness-to-Pay for Food Attributes. American Journal of Agricultural Economics, 91(3), 795-809. Gelski, J. (2016). Consumers not clear on clean label definition. Food Business News. Retrieved from http://www.foodbusinessnews.net/articles/news_home/Consumer_Trends/2016/02/Consumers _not_clear_on_clean_l.aspx?ID=\%7B7B7BE175-2049-4403-B1D9-

\section{A1CB8F76CFBB\%7D\&cck=1}

Gilles Laurent, J.-N. K. (1985). Measuring Consumer Involvement Profiles. Journal of Marketing Research, 22(1), 41-53.

Gineikiene, J., Kiudyte, J., \& Degutis, M. (2017). Functional, organic or conventional? Food choices of health conscious and skeptical consumers. Baltic Journal of Management, 12(2), $139-152$.

Godfray, H. C. J., Beddington, J. R., Crute, I. R., Haddad, L., Lawrence, D., Muir, J. F., ... 
Please cite as: Asioli, Daniele; Aschemann-Witzel, Jessica; Caputo, Vincenzina; Vecchio, Riccardo; Annunziata, Azzurra; Næs, Tormod; Varela, Paula. Making sense of the "clean label” trends: a review of consumer food choice behavior and discussion of industry implications Food Research International, 99, 58-71. https://doi.org/10.1016/j.foodres.2017.07.022

Toulmin, C. (2010). Food Security: The Challenge of Feeding 9 Billion People. Science, 327(5967), 812-818.

Grunert, K. G. (2013). Trends in food choice and nutrition. In M. Klopčič, A. Kuipers, \& J.-F. Hocquette (Eds.), Consumer attitudes to food quality products: Emphasis on Southern Europe (pp. 23-30). Wageningen: Wageningen Academic Publishers.

Grunert, K. G., Bredahl, L., \& Scholderer, J. (2003). Four questions on European consumers’ attitudes toward the use of genetic modification in food production. Innovative Food Science \& Emerging Technologies, 4(4), 435-445.

Grzybowska-Brzezinska, M., Grzywinska-Rapca, M., Zuchowski, I., \& Borawski, P. (2017). Organic Food Attributes Determing Consumer Choices. European Research Studies Journal, O(2A), 164-176.

Haen, D. (2014). The Paradox of E-Numbers: Ethical, Aesthetic, and Cultural Concerns in the Dutch Discourse on Food Additives. Journal of Agricultural and Environmental Ethics, 27(1), $27-42$.

Hasimu, H., Marchesini, S., \& Canavari, M. (2017). A concept mapping study on organic food consumers in Shanghai, China. Appetite, 108, 191-202.

Hauser, M., Jonas, K., \& Riemann, R. (2011). Measuring salient food attitudes and food-related values. An elaborated, conflicting and interdependent system. Appetite, 57(2), 329-338.

Hemmerling, S., Asioli, D., \& Spiller, A. (2016). Core Organic Taste: Preferences for NaturalnessRelated Sensory Attributes of Organic Food Among European Consumers. Journal of Food Products Marketing, 22(7), 824-850.

Hemmerling, S., Canavari, M., \& Spiller, A. (2016). Preference for naturalness of European organic 
Please cite as: Asioli, Daniele; Aschemann-Witzel, Jessica; Caputo, Vincenzina; Vecchio, Riccardo; Annunziata, Azzurra; Næs, Tormod; Varela, Paula. Making sense of the "clean label” trends: a review of consumer food choice behavior and discussion of industry implications Food Research International, 99, 58-71. https://doi.org/10.1016/j.foodres.2017.07.022

consumers. British Food Journal, 118(9), 2287-2307.

Hemmerling, S., Hamm, U., \& Spiller, A. (2015). Consumption behaviour regarding organic food from a marketing perspective—a literature review. Organic Agriculture, 5(4), 277-313.

Hemmerling, S., Obermowe, T., Canavari, M., Sidali, K. L., Stolz, H., \& Spiller, A. (2013).

Organic food labels as a signal of sensory quality---insights from a cross-cultural consumer survey. Organic Agriculture, 3(1), 57-69.

Higgins, T. E. (2005). Value From Regulatory Fit. Current Directions in Psychological Science, 14, 209-213.

Hoyer, W. D. (1984). An Examination of Consumer Decision Making for a Common Repeat Purchase Product. Journal of Consumer Research, 11(3), 822-829.

Husic-Mehmedovic, M., Arslanagic-Kalajdzic, M., Kadic-Maglajlic, S., \& Vajnberger, Z. (2017). Live, Eat, Love: life equilibrium as a driver of organic food purchase. British Food Journal, 119(7), 1410-1422.

IFOAM. (2015). Into the future. Consolidated Annual Report. http://www.ifoam.bio/sites/default/files/annual_report_2015_0.pdf

Ingredion. (2014). The clean label guide in Europe. Retrieved from http://www.alimentatec.com/wp-content/uploads/2014/10/The-Clean-Label-Guide-ToEurope.pdf

Janssen, M., \& Hamm, U. (2012a). Product labelling in the market for organic food: Consumer preferences and willingness-to-pay for different organic certification logos. Food Quality and Preference, 25(1), 9-22.

Janssen, M., \& Hamm, U. (2012b). The mandatory EU logo for organic food: consumer 
Please cite as: Asioli, Daniele; Aschemann-Witzel, Jessica; Caputo, Vincenzina; Vecchio, Riccardo; Annunziata, Azzurra; Næs, Tormod; Varela, Paula. Making sense of the "clean label” trends: a review of consumer food choice behavior and discussion of industry implications Food Research International, 99, 58-71. https://doi.org/10.1016/j.foodres.2017.07.022

perceptions. British Food Journal, 114(3), 335-352.

Joppen, L. (2006). Taking out the chemistry. Food Engineering \& Ingredients, 31(2), 38.

Kang, H.-J., Kim, S., Lee, G., Lim, H. S., Yun, S. S., \& Kim, J.-W. (2017). Perception Gaps on Food Additives among Various Groups in Korea: Food Experts, Teachers, Nutrition Teachers, Nongovernmental Organization Members, and General Consumers. Journal of Food Protection, 80(6), 1015-1021.

Katz, B., \& Williams, L. A. (2011). Cleaning up processed foods. Food Technology, 65(12), 33.

Kearney, J. (2010). Food consumption trends and drivers. Philosophical Transactions of the Royal Society B: Biological Sciences, 365(1554), 2793-2807.

Kitchen, J. P., Kerr, G., Schultz, D., McColl, R., \& Pals, H. (2014). The elaboration likelihood model: review, critique and research agenda. European Journal of Marketing, 48(11/12), 2033-2050.

Knowles, T., Moody, R., \& McEachern, M. G. (2007). European food scares and their impact on EU food policy. British Food Journal, 109(1), 43-67.

Knowx, S., \& Walker, D. (2003). Empirical developments in the measurement of involvement, brand loyalty and their relationship in grocery markets. Journal of Strategic Marketing, 11(4), 271-286.

Köster, E. P. (2009). Diversity in the determinants of food choice: A psychological perspective. Food Quality and Preference, 20(2), 70-82.

Kriwy, P., \& Mecking, R.-A. (2012). Health and environmental consciousness, costs of behaviour and the purchase of organic food. International Journal of Consumer Studies, 36(1), 30-37.

Krovetz, H. (2016). The Effect of Water-Use Labeling and Information on Consumer Valuation for 
Please cite as: Asioli, Daniele; Aschemann-Witzel, Jessica; Caputo, Vincenzina; Vecchio, Riccardo; Annunziata, Azzurra; Næs, Tormod; Varela, Paula. Making sense of the "clean label” trends: a review of consumer food choice behavior and discussion of industry implications Food Research International, 99, 58-71. https://doi.org/10.1016/j.foodres.2017.07.022

WaterSustainable Food Choices in California. University of California at Berkeley, Berkeley, California.

Kubota, S., Sawano, H., \& Kono, H. (2017). Japanese consumer preferences for additive-free wine labeling. Agricultural and Food Economics, 5(1), 4.

Lachat, C., Nago, E., Verstraeten, R., Roberfroid, D., Van Camp, J., \& Kolsteren, P. (2012). Eating out of home and its association with dietary intake: a systematic review of the evidence. Obesity Reviews : An Official Journal of the International Association for the Study of Obesity, 13(4), 329-46.

Lee, W. J., Shimizu, M., Kniffin, K. M., \& Wansink, B. (2013). You taste what you see: Do organic labels bias taste perceptions? Food Quality and Preference, 29(1), 33-39.

Li, M., \& Chapman, G. B. (2012). Why Do People Like Natural? Instrumental and Ideational Bases for the Naturalness Preference. Journal of Applied Social Psychology, 42(12), 2859-2878.

Liang, R.-D. (2016). Predicting intentions to purchase organic food: the moderating effects of organic food prices. British Food Journal, 118(1), 183-199.

Liu, R., Hooker, N. H., Parasidis, E., \& Simons, C. T. (2017). A Natural Experiment: Using Immersive Technologies to Study the Impact of “All-Natural” Labeling on Perceived Food Quality, Nutritional Content, and Liking. Journal of Food Science, 82(3), 825-833.

Lofstedt, R. E. (2008). Risk Communication, Media Amplification and the Aspartame Scare. Risk Management, 10(4), 257-284.

Lofstedt, R. E. (2009). Risk communication and the FSA: the food colourings case. Journal of Risk Research, 12(5), 537-557.

Lucová, M., Hojerová, J., Pažoureková, S., \& Klimová, Z. (2013). Absorption of triphenylmethane 
Please cite as: Asioli, Daniele; Aschemann-Witzel, Jessica; Caputo, Vincenzina; Vecchio, Riccardo; Annunziata, Azzurra; Næs, Tormod; Varela, Paula. Making sense of the "clean label” trends: a review of consumer food choice behavior and discussion of industry implications Food Research International, 99, 58-71. https://doi.org/10.1016/j.foodres.2017.07.022

dyes Brilliant Blue and Patent Blue through intact skin, shaven skin and lingual mucosa from daily life products. Food and Chemical Toxicology, 52, 19-27.

Lunardo, R., \& Saintives, C. (2013). The effect of naturalness claims on perceptions of food product naturalness in the point of purchase. Journal of Retailing and Consumer Services, 20(6), 529-537.

Lupton, D. A. (2005). Lay discourses and beliefs related to food risks: an Australian perspective. Sociology of Health \& Illness, 27(4), 448-467.

Lusk, J. L. (2016). Unnaturally Delicious: How Science and Technology are Serving Up Super Foods to Save the World. New York: St. Martin’s Press.

MacFie, H. J. H. (2007). Consumer-Led Food Product Development. (MacFie H, Ed.). Cambridge: Woodhead Publishing Limitated.

Magnier, L., Schoormans, J., \& Mugge, R. (2016). Judging a product by its cover: Packaging sustainability and perceptions of quality in food products. Food Quality and Preference, 53, $132-142$.

Marian, L., Chrysochou, P., Krystallis, A., \& Thøgersen, J. (2014). The role of price as a product attribute in the organic food context: An exploration based on actual purchase data. Food Quality and Preference, 37, 52-60.

Martins, N., Roriz, C. L., Morales, P., Barros, L., \& Ferreira, I. C. F. R. (2016). Food colorants: Challenges, opportunities and current desires of agro-industries to ensure consumer expectations and regulatory practices. Trends in Food Science \& Technology, 52, 1-15.

McFadden, J. R., \& Huffman, W. E. (2017). Willingness-to-pay for natural, organic, and conventional foods: The effects of information and meaningful labels. Food Policy, 68, 214- 
Please cite as: Asioli, Daniele; Aschemann-Witzel, Jessica; Caputo, Vincenzina; Vecchio, Riccardo; Annunziata, Azzurra; Næs, Tormod; Varela, Paula. Making sense of the "clean label” trends: a review of consumer food choice behavior and discussion of industry implications Food Research International, 99, 58-71. https://doi.org/10.1016/j.foodres.2017.07.022

232.

Meneses, Y., Cannon, K. J., \& Flores, R. A. (2014). Keys to understanding and addressing consumer perceptions and concerns about processed foods. Cereals Foods Worlds, 59(3), 141146.

Mick, D. G., Broniarczyk, S. M., \& Haidt, J. (2004). Choose, Choose, Choose, Choose, Choose, Choose, Choose: Emerging and Prospective Research on the Deleterious Effects of Living in Consumer Hyperchoice. Journal of Business Ethics, 52(2), 207-211.

Mintel. (2015). Mintel serves up 5 key food and drink trends for 2015.

Mørk, T., Bech-Larsen, T., Grunert, K. G., \& Tsalis, G. (2017). Determinants of citizen acceptance of environmental policy regulating consumption in public settings: Organic food in public institutions. Journal of Cleaner Production, 148, 407-414.

Mosby, I. (2009). “That Won-Ton Soup Headache”: The Chinese Restaurant Syndrome, MSG and the Making of American Food, 1968-1980. Social History of Medicine, 22(1), 133-151.

Moskowitz, H. R., Beckley, J. H., \& Resurreccion, A. V. A. (2012). So What are the Practical Considerations in Actually Running a Test? What do I need to know? What does the Rest of the Company Need to Know? In Sensory and Consumer Research in Food Product Design and Development (pp. 321-363). Wiley-Blackwell.

Nuttavuthisit, K., \& Thøgersen, J. (2017). The Importance of Consumer Trust for the Emergence of a Market for Green Products: The Case of Organic Food. Journal of Business Ethics, 140(2), $323-337$.

Osborne, S. (2015). Labelling relating to natural ingredients and additives. Advances in Food and Beverage Labelling: Information and Regulations, 207-221. 
Please cite as: Asioli, Daniele; Aschemann-Witzel, Jessica; Caputo, Vincenzina; Vecchio, Riccardo; Annunziata, Azzurra; Næs, Tormod; Varela, Paula. Making sense of the "clean label”, trends: a review of consumer food choice behavior and discussion of industry implications Food Research International, 99, 58-71. https://doi.org/10.1016/j.foodres.2017.07.022

Pagliarini, E., Laureati, M., \& Gaeta, D. (2013). Sensory descriptors, hedonic perception and consumer's attitudes to Sangiovese red wine deriving from organically and conventionally grown grapes. Frontiers in Psychology, 4, 896.

Paul, J., \& Rana, J. (2012). Consumer behavior and purchase intention for organic food. Journal of Consumer Marketing, 29(6), 412-422.

Petrescu, D. C., Petrescu-Mag, R. M., Burny, P., \& Azadi, H. (2017). A new wave in Romania: organic food. Consumers' motivations, perceptions, and habits. Agroecology and Sustainable Food Systems, 41(1), 46-75.

Petty, R. E., Cacioppo, J. T., \& Schumann, D. (1983). Central and Peripheral Routes to Advertising Effectiveness: The Moderating Role of Involvement. Journal of Consumer Research, 10, 135146.

Pino, G., Peluso, A. M., \& Guido, G. (2012). Determinants of Regular and Occasional Consumers’ Intentions to Buy Organic Food. Journal of Consumer Affairs, 46(1), 157-169.

Pollan, M. (2008). In defence of food. An eaters’ manifesto. The Penguin Press.

Princen, T. (1997). The shading and distancing of commerce: When internalization is not enough. Ecological Economics, 20(3), 235-253. Rahnama, H. (2017). Effect of Consumption Values on Women’s Choice Behavior Toward Organic Foods: The Case of Organic Yogurt in Iran. Journal of Food Products Marketing, 23(2), 144-166.

Rödiger, M., \& Hamm, U. (2015). How are organic food prices affecting consumer behaviour? A review. Food Quality and Preference, 43, 10-20.

Rollin, F., Kennedy, J., \& Wills, J. (2011). Consumers and new food technologies. In New challenges in food preservation.Processing - Safety - Sustainability EFFoST 2009 Annual 
Please cite as: Asioli, Daniele; Aschemann-Witzel, Jessica; Caputo, Vincenzina; Vecchio, Riccardo; Annunziata, Azzurra; Næs, Tormod; Varela, Paula. Making sense of the "clean label” trends: a review of consumer food choice behavior and discussion of industry implications Food Research International, 99, 58-71. https://doi.org/10.1016/j.foodres.2017.07.022

Meeting, (pp. 99-111).

Rozin, P. (2006). Naturalness judgments by lay Americans: Process dominates content in judgments of food or water acceptability and naturalness. Judgment and Decision Making, 1(2), 91-97.

Rozin, P., Fischler, C., \& Shields-Argelès, C. (2012a). European and American perspectives on the meaning of natural. Appetite, 59(2), 448-455.

Rozin, P., Spranca, M., Krieger, Z., Neuhaus, R., Surillo, D., Swerdlin, A., \& Wood, K. (2004). Preference for natural: instrumental and ideational/moral motivations, and the contrast between foods and medicines. Appetite, 43(2), 147-154.

Saltmarsh, M. (2013). Essential guide to food additives (4th ed.). Cambridge, UK: RSC: Publishing. Samant, S. S., \& Seo, H.-S. (2016). Quality perception and acceptability of chicken breast meat labeled with sustainability claims vary as a function of consumers’ label-understanding level. Food Quality and Preference, 49, 151-160.

Schiffman, L. G., \& Wisenblit, J. L. (2015). Consumer behavior. (Pearson, Ed.) (11th ed.). Boston, MA.

Schleenbecker, R., \& Hamm, U. (2013). Consumers’ perception of organic product characteristics. A review. Appetite, 71, 420-429.

Schroeder, J. (2016). Study finds consumers don’t understand ‘clean labels.”. Food Safety Quality \& Safety. http://www.foodqualityandsafety.com/article/15947/

Schuldt, J. P., \& Hannahan, M. (2013). When good deeds leave a bad taste. Negative inferences from ethical food claims. Appetite, 62, 76-83.

Shashi, Kottala, S. Y., \& Singh, R. (2015). A review of sustainability, deterrents, personal values, 
Please cite as: Asioli, Daniele; Aschemann-Witzel, Jessica; Caputo, Vincenzina; Vecchio, Riccardo; Annunziata, Azzurra; Næs, Tormod; Varela, Paula. Making sense of the "clean label” trends: a review of consumer food choice behavior and discussion of industry implications Food Research International, 99, 58-71. https://doi.org/10.1016/j.foodres.2017.07.022

attitudes and purchase intentions in the organic food supply chain. Pacific Science Review B: Humanities and Social Sciences, 1(3), 114-123.

Shim, S. M., Seo, S. H., Lee, Y., Moon, G. I., Kim, M. S., \& Park, J. H. (2011). Consumers’ knowledge and safety perceptions of food additives: Evaluation on the effectiveness of transmitting information on preservatives. Food Control, 22(7), 1054-1060.

Siegrist, M., \& Sütterlin, B. (2017). Importance of perceived naturalness for acceptance of food additives and cultured meat. Appetite, 113, 320-326.

Siipi, H. (2013). Is Natural Food Healthy? Journal of Agricultural and Environmental Ethics, 26(4), 797-812.

Silva, A. R. de A., Bioto, A. S., Efraim, P., \& Queiroz, G. de C. (2017). Impact of sustainability labeling in the perception of sensory quality and purchase intention of chocolate consumers. Journal of Cleaner Production, 141, 11-21.

Sloan, A. E. (1999). Top ten trends to watch and work on for the millennium. Food Technology, 53(80), 40-60.

Stern, T., Haas, R., \& Meixner, O. (2009). Consumer acceptance of wood-based food additives. British Food Journal, 111(2), 179-195.

Swientik, B. (2017). Clean label. Retrieved from http://www.ift.org/General Search.aspx?s=Food Technology\&k=\%22clean label\%22\#q=\%22clean label\%22\&sort=relevancy\&f:@fiftscope90933subl_coveofacets_0=[Food Technology]\&f:@fiftyear90933subl_coveofacets_3=[2016,2015,2014,2013,2012,2011,2010,2 $009,2008,2007,200$

Szucs, V., Szabo, E., \& Bana. (2014). Factors affecting the avoidance of food additives in Hungary. 
Please cite as: Asioli, Daniele; Aschemann-Witzel, Jessica; Caputo, Vincenzina; Vecchio, Riccardo; Annunziata, Azzurra; Næs, Tormod; Varela, Paula. Making sense of the "clean label” trends: a review of consumer food choice behavior and discussion of industry implications Food Research International, 99, 58-71. https://doi.org/10.1016/j.foodres.2017.07.022

Journal of Hygienic Engineering and Design, 8, 61-66.

Tanaka, Y., Kitayama, M., Arai, S., \& Matsushima, Y. (2015). Major psychological factors affecting consumer’s acceptance of food additives: Validity of a new psychological model. British Food Journal, 117(11), 2788-2800.

Tarnavöglyi, G. (2003). Analysis of Consumers` Attitudes Towards Food Additives Using Focus Group Survey. Agriculturae Conspectus Scientificus, 68(3), 193-196.

Thøgersen, J. (2017). Sustainable food consumption in the nexus between national context and private lifestyle: A multi-level study. Food Quality and Preference, 55, 16-25.

Thøgersen, J., de Barcellos, M. D., Perin, M. G., \& Zhou, Y. (2015). Consumer buying motives and attitudes towards organic food in two emerging markets: China and Brazil. International Marketing Review, 32(3/4), 389-413.

Thompson, D. B. (2011). Natural Food and the Pastoral: A Sentimental Notion? Journal of Agricultural and Environmental Ethics, 24(2), 165-194.

van Kleef, E., van Trijp, H. C. M., \& Luning, P. (2005). Functional foods: health claim-food product compatibility and the impact of health claim framing on consumer evaluation. Appetite, 44(3), 299-308.

Van Kleef, E., Van Trijp, H. C. M., \& Luning, P. (2005). Consumer research in the early stages of new product development: a critical review of methods and techniques. Food Quality and Preference, 16(3), 181-201.

Van Loo, E., Caputo, V., Jr., R. M. N., Seo, H.-S., Zhang, B., \& Verbeke, W. (2015). Sustainability labels on coffee: Consumer preferences, willingness-to-pay and visual attention to attributes. Ecological Economics, 118, 215-225. 
Please cite as: Asioli, Daniele; Aschemann-Witzel, Jessica; Caputo, Vincenzina; Vecchio, Riccardo; Annunziata, Azzurra; Næs, Tormod; Varela, Paula. Making sense of the "clean label” trends: a review of consumer food choice behavior and discussion of industry implications Food Research International, 99, 58-71. https://doi.org/10.1016/j.foodres.2017.07.022

Van Loo, E., Caputo, V., Nayga, R., \& Verbeke, W. (2014). Consumers’ valuation of sustainability labels on meat. Food Policy, 49, Part 1, 137-150.

Van Loo, E. J., Caputo, V., Nayga, R. M., Meullenet, J.-F., \& Ricke, S. C. (2011). Consumers’ willingness to pay for organic chicken breast: Evidence from choice experiment. Food Quality and Preference, 22(7), 603-613.

Van Loo, Diem, M. N. H., Pieniak, Z., \& Verbeke, W. (2013). Consumer attitudes, knowledge, and consumption of organic yogurt. Journal of Dairy Science, 96(4), 2118-2129.

Varela, P., \& Fiszman, S. M. (2013). Exploring consumers’ knowledge and perceptions of hydrocolloids used as food additives and ingredients. Food Hydrocolloids, 30(1), 477-484.

Vecchio, R., \& Annunziata, A. (2015). Willingness-to-pay for sustainability-labelled chocolate: an experimental auction approach. Journal of Cleaner Production, 86, 335-342.

Vecchio, R., Annunziata, A., Krystallis, A., \& Pomarici, E. (2015). Consumers’ literacy and preferences for sustainability labels: an exploratory analysis on Italian young adults. International Journal of Globalisation and Small Business, 7(3-4), 221-233.

Vecchio, R., Van Loo, E. J., \& Annunziata, A. (2016). Consumers’ willingness to pay for conventional, organic and functional yogurt: evidence from experimental auctions. International Journal of Consumer Studies, 40(3), 368-378.

Vlaeminck, P., Jiang, T., \& Vranken, L. (2014). Food labeling and eco-friendly consumption: Experimental evidence from a Belgian supermarket. Ecological Economics, 108, 180-190.

Wansink, B., Tal, A., \& Brumberg, A. (2014). Ingredient-based food fears and avoidance: Antecedents and antidotes. Food Quality and Preference, 38, 40-48.

Weaver, C. M., Dwyer, J., Fulgoni, V. L., King, J. C., Leveille, G. A., MacDonald, R. S., ... 
Please cite as: Asioli, Daniele; Aschemann-Witzel, Jessica; Caputo, Vincenzina; Vecchio, Riccardo; Annunziata, Azzurra; Næs, Tormod; Varela, Paula. Making sense of the "clean label” trends: a review of consumer food choice behavior and discussion of industry implications Food Research International, 99, 58-71. https://doi.org/10.1016/j.foodres.2017.07.022

Schnakenberg, D. (2014). Processed foods: contributions to nutrition. The American Journal of Clinical Nutrition, 99(6), 1525-42.

Weis, T. (2007). The Global Food Economy: The Battle for the Future of Farming. Canada: Fernowood Publishing.

Wu, L., Zhong, Y., Shan, L., \& Qin, W. (2013). Public risk perception of food additives and food scares. The case in Suzhou, China. Appetite, 70, 90-98.

Zagata, L. (2012). Consumers' beliefs and behavioural intentions towards organic food. Evidence from the Czech Republic. Appetite, 59(1), 81-89.

Zander, K. (2014). A Green Leaf!? Consumers’ Knowledge and Perception of the Mandatory EU Organic Logo. In Proceedings of the 4th International European Forum on System Dynamics and Innovation in Food Networks (pp. 220-228). Innsbruck, Austria.

Zander, K., Padel, S., \& Zanoli, R. (2015). EU organic logo and its perception by consumers. British Food Journal, 117(5), 1506-1526.

Zanoli, R., Scarpa, R., Napolitano, F., Piasentier, E., Naspetti, S., \& Bruschi, V. (2013). Organic label as an identifier of environmentally related quality: A consumer choice experiment on beef in Italy. Renewable Agriculture and Food Systems, 28(1), 70-79.

Zink, D. L. (1997). The impact of consumer demands and trends on food processing. Emerging Infectious Diseases, 3(4), 467-469. 
Please cite as: Asioli, Daniele; Aschemann-Witzel, Jessica; Caputo, Vincenzina; Vecchio, Riccardo; Annunziata, Azzurra; Næs, Tormod; Varela, Paula. Making sense of the "clean label” trends: a review of consumer food choice behavior and discussion of industry implications Food Research International, 99, 58-71. https://doi.org/10.1016/j.foodres.2017.07.022

\section{APPENDIX A:}

Table A.1 - Selected papers concerning the factors that drive consumers' perceptions and preferences for organic labeled food products.

$$
\text { <<Please, place here Table A.1 >> }
$$

Table A.2 - Selected papers concerning the factors that drive consumers' perceptions and preferences for natural food products.

$$
\text { <<Please, place here Table A.2>> }
$$


Please cite as: Asioli, Daniele; Aschemann-Witzel, Jessica; Caputo, Vincenzina; Vecchio, Riccardo; Annunziata, Azzurra; Næs, Tormod; Varela, Paula. Making sense of the "clean label" trends: a review of consumer food choice behavior and discussion of industry implications Food Research International, 99, 58-71. https://doi.org/10.1016/j.foodres.2017.07.022

Table A.3 - Selected papers concerning the factors that drive consumers' perceptions and preferences for food "free from artificial additives/ingredients".

<<Please, place here Table A.3 >> 
Please cite as: Asioli, Daniele; Aschemann-Witzel, Jessica; Caputo, Vincenzina; Vecchio, Riccardo; Annunziata, Azzurra; Næs, Tormod; Varela, Paula. Making sense of the "clean label" trends: a review of consumer food choice behavior and discussion of industry implications Food Research International, 99, 58-71. https://doi.org/10.1016/j.foodres.2017.07.022

Figure 1 - A proposed definition and concept of 'clean label'

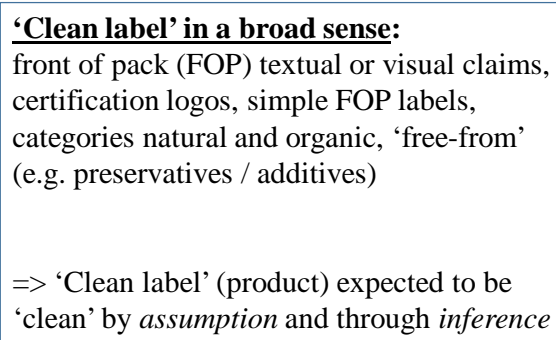

\section{'Clean label' in a strict sense:}

back of pack (BOP) ingredient list and nutrition facts panel, characterized by being short, simple, no artificial ingredients, not 'chemical-sounding', with 'kitchen cupboard ingredients' that are expected and familiar

$=>$ 'Clean label' (that is: ingredient information) found 'clean' on inspection 
Please cite as: Asioli, Daniele; Aschemann-Witzel, Jessica; Caputo, Vincenzina; Vecchio, Riccardo; Annunziata, Azzurra; Næs, Tormod; Varela, Paula. Making sense of the "clean label” trends: a review of consumer food choice behavior and discussion of industry implications Food Research International, 99, 58-71. https://doi.org/10.1016/j.foodres.2017.07.022

Figure 2 - Essential factors and sub-factors that influence eating and drinking behaviour and food choice.

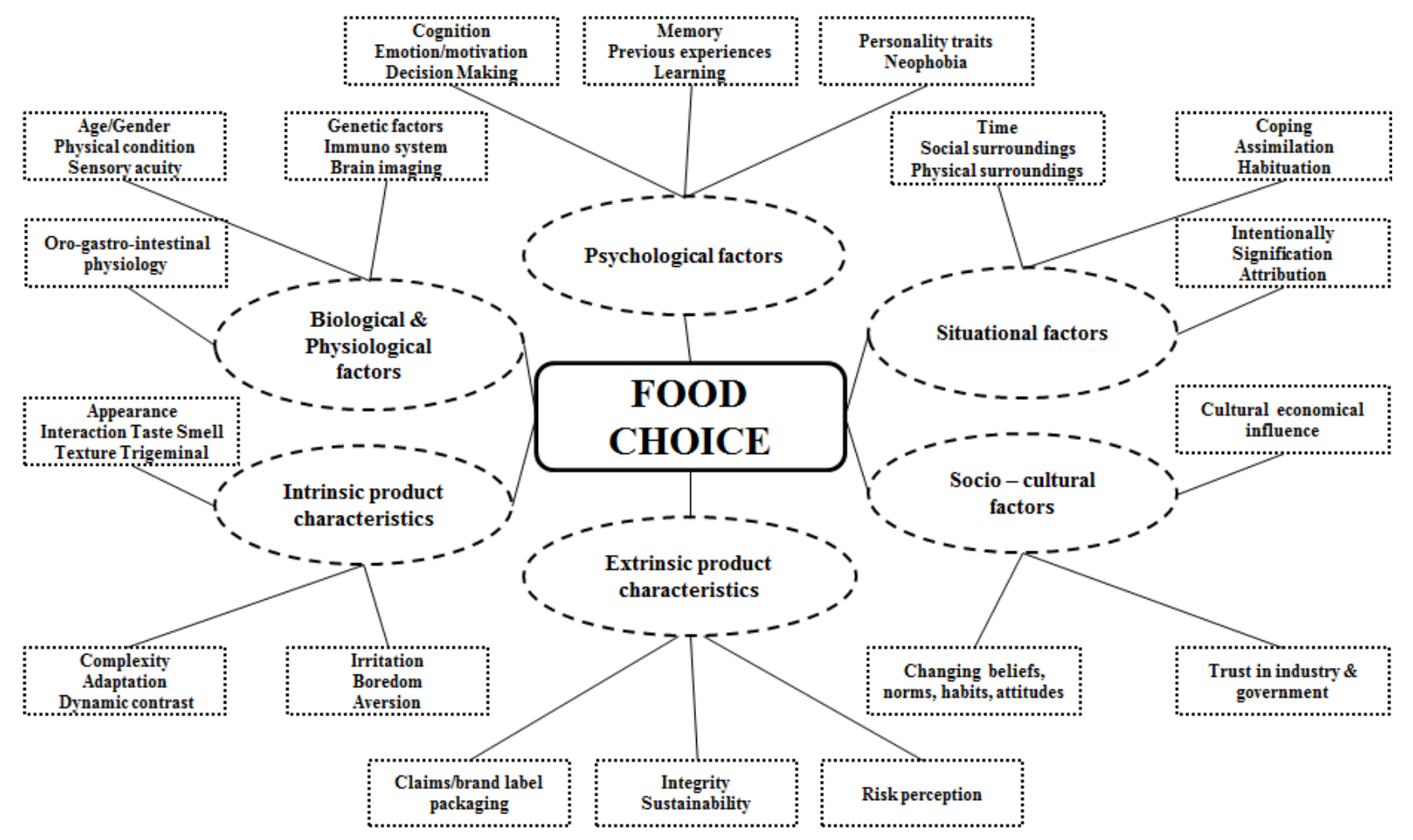

Source: adapted from Koster (2009) 
Please cite as: Asioli, Daniele; Aschemann-Witzel, Jessica; Caputo, Vincenzina; Vecchio, Riccardo; Annunziata, Azzurra; Næs, Tormod; Varela, Paula. Making sense of the "clean label” trends: a review of consumer food choice behavior and discussion of industry implications Food Research International, 99, 58-71. https://doi.org/10.1016/j.foodres.2017.07.022

Figure 3 - Essential factors that drive consumers' perceptions and preferences for organic labeled food products: adapted from Mojet model. Sub-factors were identified from the literature review of 54 papers on "organic".

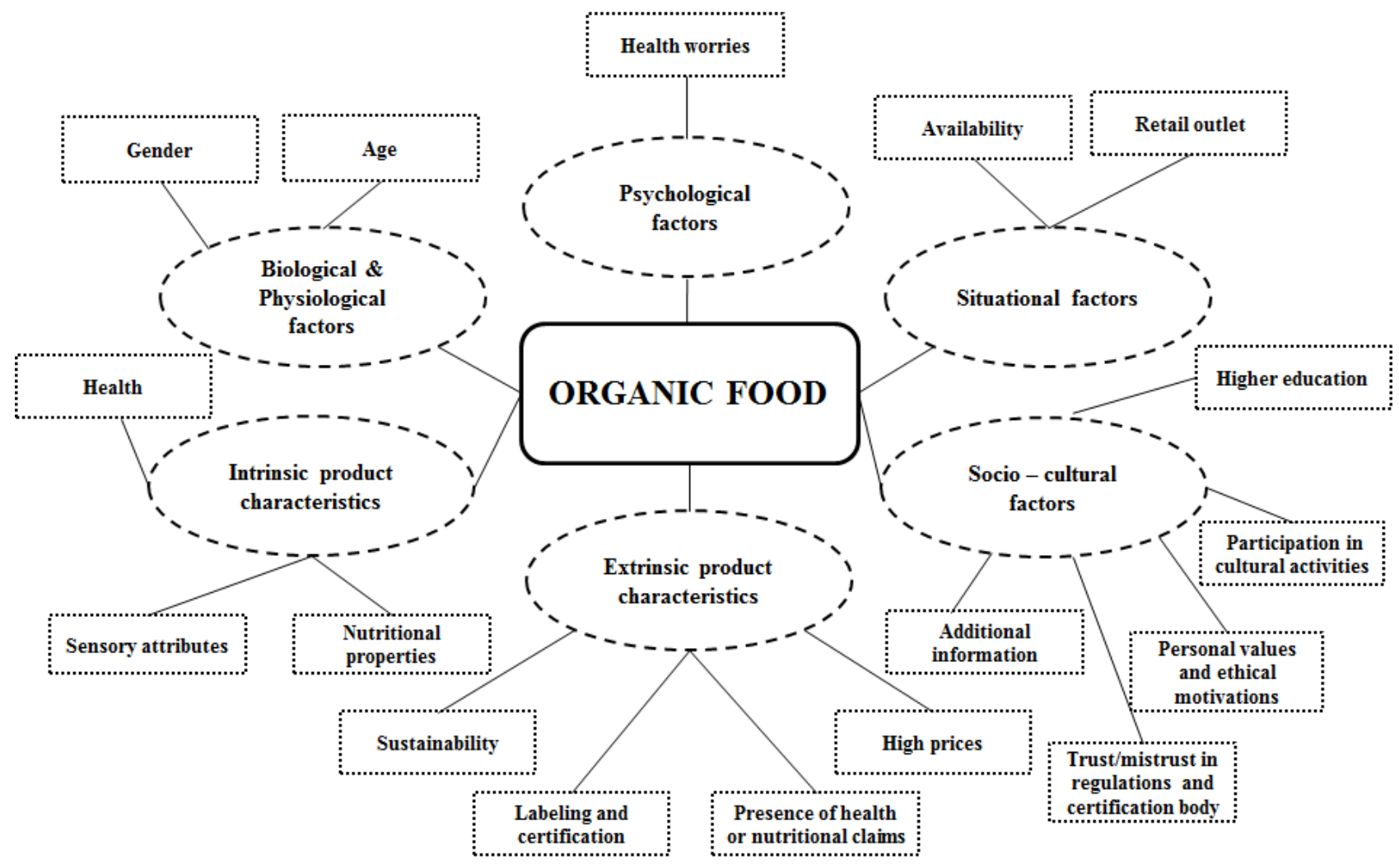


Please cite as: Asioli, Daniele; Aschemann-Witzel, Jessica; Caputo, Vincenzina; Vecchio, Riccardo; Annunziata, Azzurra; Næs, Tormod; Varela, Paula. Making sense of the "clean label” trends: a review of consumer food choice behavior and discussion of industry implications Food Research International, 99, 58-71. https://doi.org/10.1016/j.foodres.2017.07.022

Figure 4-Essential factors that drive consumers' perceptions and preferences for natural food products: adapted from Mojet model. Sub-factors were identified from the literature review of 25 papers on "natural".

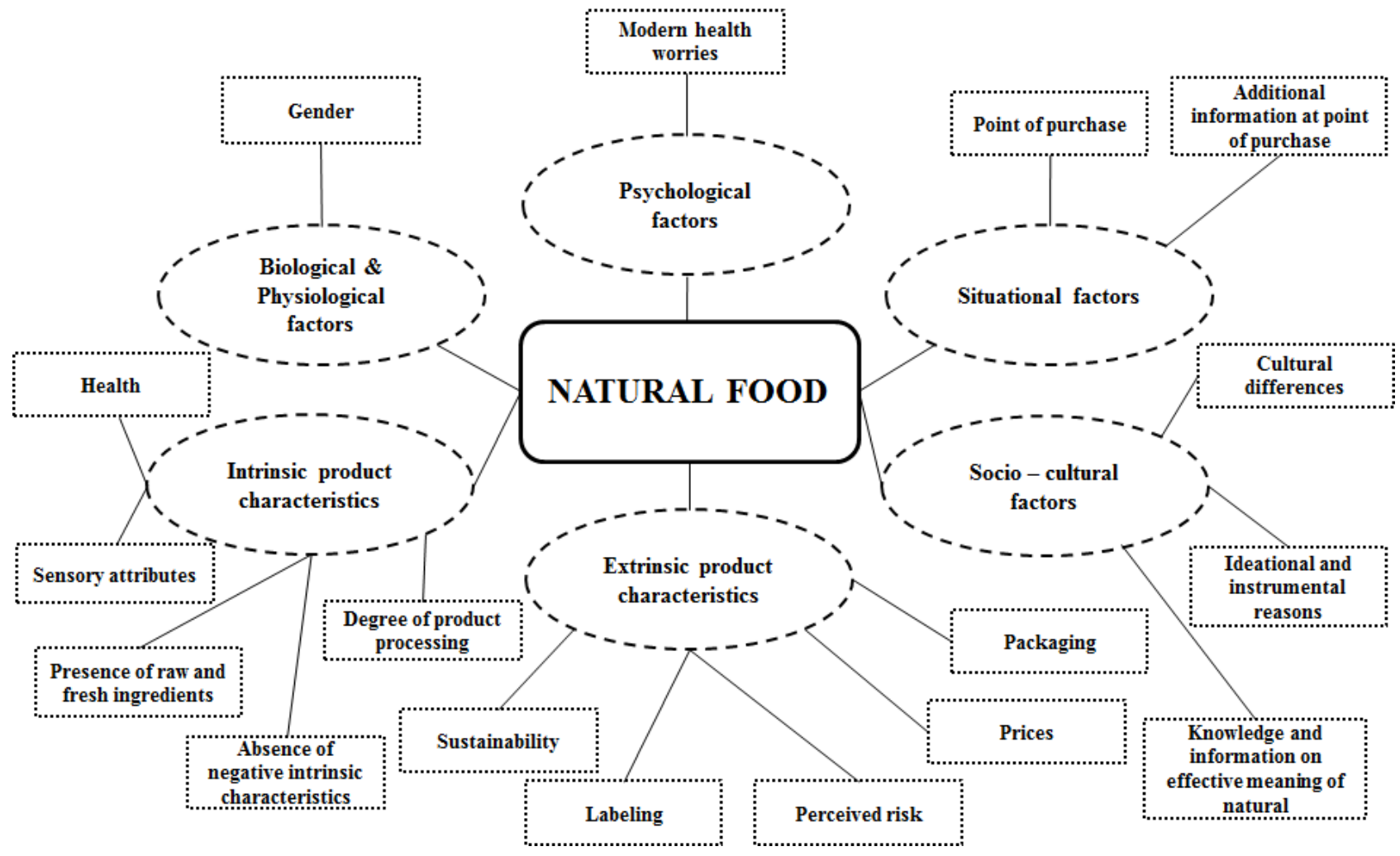


Please cite as: Asioli, Daniele; Aschemann-Witzel, Jessica; Caputo, Vincenzina; Vecchio, Riccardo; Annunziata, Azzurra; Næs, Tormod; Varela, Paula. Making sense of the "clean label” trends: a review of consumer food choice behavior and discussion of industry implications Food Research International, 99, 58-71. https://doi.org/10.1016/j.foodres.2017.07.022

Figure 5-Essential factors that drive consumers' perceptions and preferences for food "free from artificial additives/ingredients": adapted from Mojet model. Sub-factors were identified from the literature review of 16 papers on "free from artificial additives/ingredients".

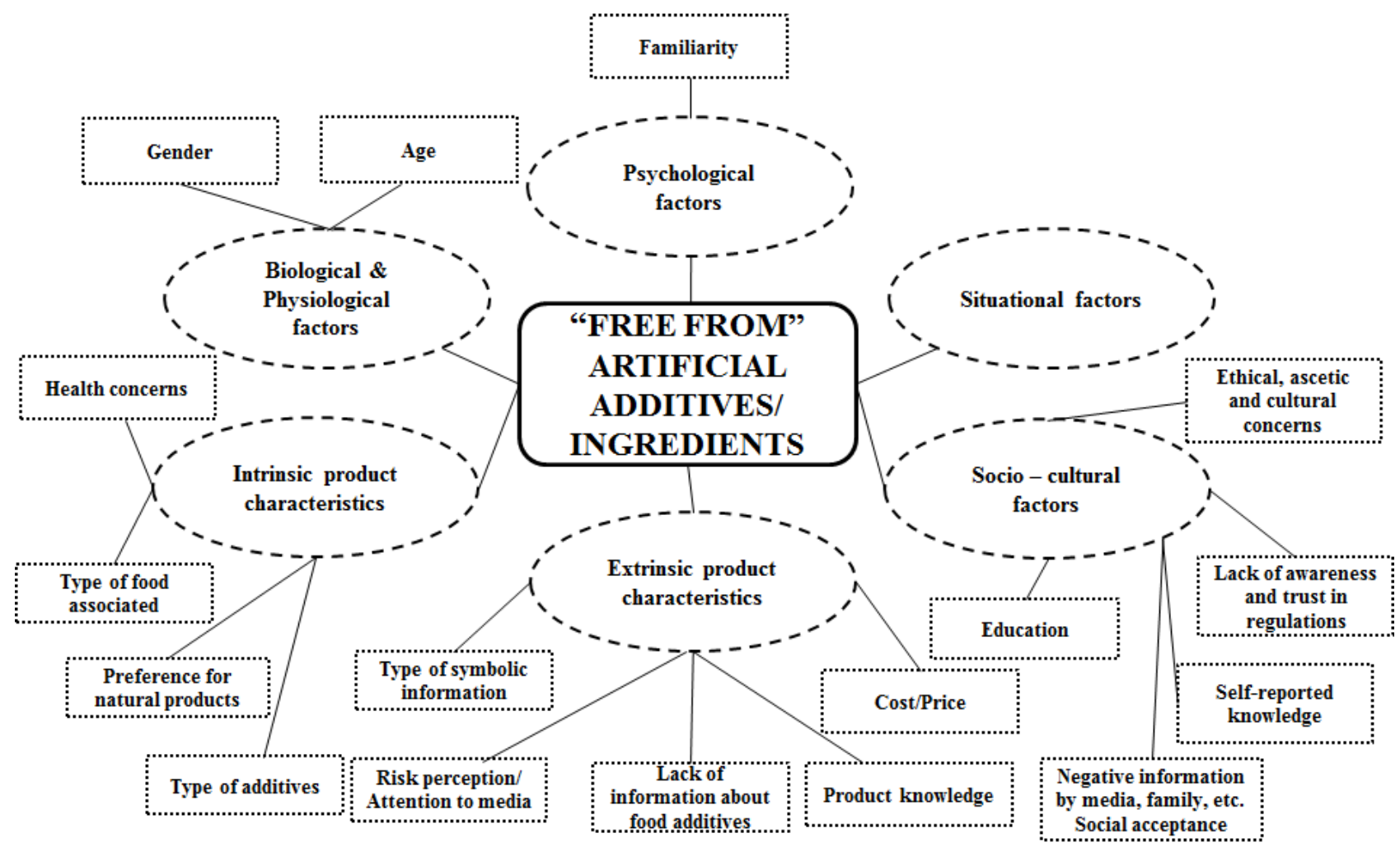


Please cite as: Asioli, Daniele; Aschemann-Witzel, Jessica; Caputo, Vincenzina; Vecchio, Riccardo; Annunziata, Azzurra; Næs, Tormod; Varela, Paula. Making sense of the "clean label” trends: a review of consumer food choice behavior and discussion of industry implications Food Research International, 99, 58-71. https://doi.org/10.1016/j.foodres.2017.07.022

Table A.1 - Selected papers concerning the factors that drive consumers' perceptions and preferences for organic labeled food products.

\begin{tabular}{|c|c|c|c|c|}
\hline $\mathbf{N}^{\circ}$ & AUTHORS & YEAR & COUNTRY & MAIN FINDINGS \\
\hline 1 & $\begin{array}{l}\text { Aertsens, J., Verbeke, W., } \\
\text { Mondelaers, K., \& Van } \\
\text { Huylenbroeck, G. }\end{array}$ & 2009 & n.a. ${ }^{*}$ & $\begin{array}{l}\text { Organic food consumption decisions can be } \\
\text { explained by relating attributes of organic food } \\
\text { products with more abstract values such as security, } \\
\text { universalism, benevolence, stimulation, self- } \\
\text { direction and conformity. }\end{array}$ \\
\hline 2. & $\begin{array}{l}\text { Agovino, M., Crociata, A., } \\
\text { Quaglione, D., Sacco, P., \& } \\
\text { Sarra, A. }\end{array}$ & 2017 & Italy & $\begin{array}{l}\text { Participation in cultural activities has a positive } \\
\text { impact on the tendency to purchase organic food } \\
\text { products, to an extent that depends on the social } \\
\text { orientation of cultural activities. }\end{array}$ \\
\hline 3. & $\begin{array}{l}\text { Asioli, D., Canavari, M., } \\
\text { Pignatti, E., Obermowe, T., } \\
\text { Sidali, K. L., Vogt, C., \& } \\
\text { Spiller, A. }\end{array}$ & 2014 & $\begin{array}{c}\text { Italy } \\
\text { Germany }\end{array}$ & $\begin{array}{l}\text { Flavor and odor are the most important attributes in } \\
\text { driving organic consumers' preferences. }\end{array}$ \\
\hline 4. & $\begin{array}{l}\text { Aschemann-Witzel, J., } \\
\text { Maroscheck, N., \& Hamm, } \\
\text { U. }\end{array}$ & 2013 & Germany & $\begin{array}{l}\text { Occasional organic buyers prefer organic food with } \\
\text { health claims. }\end{array}$ \\
\hline 5. & $\begin{array}{l}\text { Aschemann-W itzel, J. and } \\
\text { Niebuhr Aagaard, E. M. }\end{array}$ & 2014 & Denmark & $\begin{array}{l}\text { Price represents a core barrier for young consumers } \\
\text { for organic food purchases, but only temporary. } \\
\text { This is because consumers argue that they postpone } \\
\text { organic purchases to a later stage in life. }\end{array}$ \\
\hline 6. & $\begin{array}{l}\text { Aschemann-W itzel, J. \& } \\
\text { Zielke, S. }\end{array}$ & 2017 & n.a.* & $\begin{array}{l}\text { Price is perceived as a main barrier to purchase } \\
\text { organic foods. }\end{array}$ \\
\hline 7. & Bernard, J.C. \& Liu, Y. & 2017 & United States & $\begin{array}{l}\text { Consumers beliefs about taste of organic and local } \\
\text { food products play a stronger role in taste }\end{array}$ \\
\hline
\end{tabular}


Please cite as: Asioli, Daniele; Aschemann-Witzel, Jessica; Caputo, Vincenzina; Vecchio, Riccardo; Annunziata, Azzurra; Næs, Tormod; Varela, Paula. Making sense of the "clean label” trends: a review of consumer food choice behavior and discussion of industry implications Food Research International, 99, 58-71. https://doi.org/10.1016/j.foodres.2017.07.022

\begin{tabular}{|c|c|c|c|c|}
\hline & & & & perceptions than actual taste. \\
\hline 8. & $\begin{array}{l}\text { Bi, X., Gao, Z., House, L. } \\
\text { A., \& Hausmann, D. S. }\end{array}$ & 2015 & United States & $\begin{array}{l}\text { Consumers' willingness to pay for sensory } \\
\text { attributes is negative for juice labelled as organic. }\end{array}$ \\
\hline 9. & $\begin{array}{l}\text { Bravo, P. C., Cordts, A., } \\
\text { Schulze, B., and Spiller, A. }\end{array}$ & 2013 & Germany & $\begin{array}{l}\text { Altruistic motives, such as animal welfare and fair } \\
\text { trade, are strong predictors of consumers' } \\
\text { purchasing of organic food. }\end{array}$ \\
\hline 10. & $\begin{array}{l}\text { Bruschi, V., Shershneva, } \\
\text { K., Dolgopolova, I., } \\
\text { Canavari, M., \& Teuber, R. }\end{array}$ & 2015 & Russia & $\begin{array}{l}\text { Organic food consumption is mainly motivated by } \\
\text { personal well-being and less by social or } \\
\text { environmental concerns issues. } \\
\text { Despite the high price for organic food, it is not } \\
\text { seen as an absolute barrier to purchase. }\end{array}$ \\
\hline 11. & Bryła, P. & 2016 & Poland & $\begin{array}{l}\text { Consumers consider healthiness and high quality as } \\
\text { the most important characteristics of organic food } \\
\text { products. }\end{array}$ \\
\hline 12. & $\begin{array}{l}\text { de-Magistris, T., \& Gracia, } \\
\text { A. }\end{array}$ & 2016 & Spain & $\begin{array}{l}\text { Consumers are willing to pay higher prices for } \\
\text { organic labelled and locally produced almonds. }\end{array}$ \\
\hline 13. & $\begin{array}{l}\text { Dimitri, C., \& Dettmann, R. } \\
\text { L. }\end{array}$ & 2012 & United States & $\begin{array}{l}\text { Consumer education level has a strong effect on the } \\
\text { likelihood of buying organic fruit and vegetables. }\end{array}$ \\
\hline 14. & $\begin{array}{l}\text { Drexler, D., Fiala, J., } \\
\text { Havlíčková, A., Potůčková, } \\
\text { A., \& Souček, M. }\end{array}$ & 2017 & Czech Republic & $\begin{array}{l}\text { Organic product labelling plays a central role in } \\
\text { determining consumer decision-making. }\end{array}$ \\
\hline 15. & $\begin{array}{l}\text { Dumortier, J., Evans, K. S., } \\
\text { Grebitus, C., \& Martin, P. } \\
\text { A. }\end{array}$ & 2017 & United States & $\begin{array}{l}\text { Organic food purchases are determined by health, } \\
\text { nutrition, and taste. General trust and trust in media } \\
\text { are also significant in influencing organic } \\
\text { purchases. }\end{array}$ \\
\hline 16. & $\begin{array}{l}\text { Ellison, B., Duff, B. R., } \\
\text { Wang, Z., \& White, T. B. }\end{array}$ & 2016 & United States & $\begin{array}{l}\text { Retail outlets are a crucial factor in influencing } \\
\text { consumers perception of organic food products, }\end{array}$ \\
\hline
\end{tabular}


Please cite as: Asioli, Daniele; Aschemann-Witzel, Jessica; Caputo, Vincenzina; Vecchio, Riccardo; Annunziata, Azzurra; Næs, Tormod; Varela, Paula. Making sense of the "clean label” trends: a review of consumer food choice behavior and discussion of industry implications Food Research International, 99, 58-71. https://doi.org/10.1016/j.foodres.2017.07.022

\begin{tabular}{|c|c|c|c|c|}
\hline & & & & influencing both expected taste and trust in brand. \\
\hline 17. & $\begin{array}{l}\text { Gineikiene, J., Kiudyte, J., } \\
\text { \& Degutis, M. }\end{array}$ & 2017 & Lithuania & $\begin{array}{l}\text { Consumers are skeptical about the health claims in } \\
\text { terms of perceived healthiness of both organic and } \\
\text { conventional products. }\end{array}$ \\
\hline 18. & $\begin{array}{l}\text { Grzybowska-Brzezinska, } \\
\text { M., Grzywinska-Rapca, M., } \\
\text { Zuchowski, I., \& Bórawski, } \\
\text { P. }\end{array}$ & 2017 & Poland & $\begin{array}{l}\text { The most important technological attribute of } \\
\text { organic food is the production method, which } \\
\text { ensures that the food is healthy, contains no } \\
\text { chemical additives and has good, natural taste. }\end{array}$ \\
\hline 19. & $\begin{array}{l}\text { Hasimu, H., Marchesini, S., } \\
\text { \& Canavari, M. }\end{array}$ & 2017 & China & $\begin{array}{l}\text { Consumers perceive organic food as healthy and } \\
\text { safe. }\end{array}$ \\
\hline 20. & $\begin{array}{l}\text { Hemmerling, S., Asioli, D., } \\
\text { \& Spiller, A. }\end{array}$ & 2016 & $\begin{array}{l}\text { Italy, } \\
\text { Germany, Poland, } \\
\text { the Netherlands, } \\
\text { Switzerland, and } \\
\text { France }\end{array}$ & $\begin{array}{l}\text { The "Core Organic Taste - COT" is not applicable } \\
\text { for all European countries. However, for most } \\
\text { countries only single elements seem to be relevant. }\end{array}$ \\
\hline 21. & $\begin{array}{l}\text { Hemmerling, S., Canavari, } \\
\text { M. and Spiller, A. }\end{array}$ & 2016 & $\begin{array}{l}\text { Germany, France, } \\
\text { Italy, Poland, } \\
\text { Switzerland, and } \\
\text { The Netherlands. }\end{array}$ & $\begin{array}{l}\text { Organic consumers reveal a positive attitude } \\
\text { towards natural food products, but a negative } \\
\text { sensory preference for the more natural yoghurt. }\end{array}$ \\
\hline 22. & $\begin{array}{l}\text { Hemmerling, S., Hamm, U., } \\
\text { and Spiller, A. }\end{array}$ & 2015 & n.a.* & $\begin{array}{l}\text { Organic food is perceived as more expensive than } \\
\text { its conventional counterpart. However, literature } \\
\text { has not yet fully addressed consumers' price } \\
\text { knowledge and price processing. }\end{array}$ \\
\hline 23. & $\begin{array}{l}\text { Hemmerling, S., } \\
\text { Obermowe, T., Canavari, } \\
\text { M., Sidali, K. L., Stolz, H., } \\
\text { \& Spiller, A. }\end{array}$ & 2013 & $\begin{array}{l}\text { Germany, France, } \\
\text { Italy, Poland, } \\
\text { Switzerland, and } \\
\text { the Netherlands }\end{array}$ & $\begin{array}{l}\text { The presence of an organic label may lead to an } \\
\text { enhancement of taste perception among consumers. }\end{array}$ \\
\hline
\end{tabular}


Please cite as: Asioli, Daniele; Aschemann-Witzel, Jessica; Caputo, Vincenzina; Vecchio, Riccardo; Annunziata, Azzurra; Næs, Tormod; Varela, Paula. Making sense of the "clean label” trends: a review of consumer food choice behavior and discussion of industry implications Food Research International, 99, 58-71. https://doi.org/10.1016/j.foodres.2017.07.022

\begin{tabular}{|c|c|c|c|c|}
\hline 24. & $\begin{array}{l}\text { Husic-Mehmedovic, M., } \\
\text { Arslanagic-Kalajdzic, M., } \\
\text { Kadic-Maglajlic, S., \& } \\
\text { Vajnberger, Z. }\end{array}$ & 2017 & $\begin{array}{l}\text { European } \\
\text { developing } \\
\text { countries }\end{array}$ & $\begin{array}{l}\text { Life equilibrium, in terms of more balanced and } \\
\text { caring approach towards one's own life, has a } \\
\text { strong, positive effect on perceived intrinsic organic } \\
\text { food quality attributes. }\end{array}$ \\
\hline 25. & Janssen, M. and Hamm, U. & 2012 & $\begin{array}{l}\text { Czech Republic, } \\
\text { Denmark, } \\
\text { Germany, Italy } \\
\text { and the UK }\end{array}$ & $\begin{array}{l}\text { Trust in the underlying production standards of EU } \\
\text { certification scheme and the inspection system was } \\
\text { not very pronounced among consumers. }\end{array}$ \\
\hline 26. & Janssen, M. and Hamm, U. & $2012 b$ & $\begin{array}{c}\text { Czech } \\
\text { Republic, } \\
\text { Denmark, } \\
\text { Germany, Italy, } \\
\text { Switzerland } \\
\text { and United } \\
\text { Kingdom. }\end{array}$ & $\begin{array}{l}\text { Only consumers trust the generic labelling with the } \\
\text { prefix 'organic' without a certification logo. For } \\
\text { almost the all tested organic certification logos, the } \\
\text { WTP was significantly higher than for the generic } \\
\text { labeling. }\end{array}$ \\
\hline 27. & $\begin{array}{l}\text { Kriwy, P., \& Mecking, R. } \\
\text { A. }\end{array}$ & 2012 & Germany & $\begin{array}{l}\text { Health consciousness has a stronger association } \\
\text { with organic food consumption. }\end{array}$ \\
\hline 28. & $\begin{array}{l}\text { Lee, W. C. J., Shimizu, M., } \\
\text { Kniffin, K. M., \& Wansink, } \\
\text { B. }\end{array}$ & 2013 & United States & $\begin{array}{l}\text { Consumers perceive food products with organic } \\
\text { labels to have larger nutritional value and lower } \\
\text { calories content than those without the organic } \\
\text { label. }\end{array}$ \\
\hline 29. & Liang, R. D. & 2016 & Taiwan & $\begin{array}{l}\text { Larger consumers' awareness of organic food } \\
\text { certification labeling enhances the sense of trust in } \\
\text { organic food labeling. }\end{array}$ \\
\hline 30. & $\begin{array}{l}\text { Marian, L., Chrysochou, P., } \\
\text { Krystallis, A., \& Thøgersen, } \\
\text { J. }\end{array}$ & 2014 & Denmark & $\begin{array}{l}\text { High price of organic food products determines less } \\
\text { repeated purchases than low or medium price. }\end{array}$ \\
\hline
\end{tabular}


Please cite as: Asioli, Daniele; Aschemann-Witzel, Jessica; Caputo, Vincenzina; Vecchio, Riccardo; Annunziata, Azzurra; Næs, Tormod; Varela, Paula. Making sense of the "clean label” trends: a review of consumer food choice behavior and discussion of industry implications Food Research International, 99, 58-71. https://doi.org/10.1016/j.foodres.2017.07.022

\begin{tabular}{|c|c|c|c|c|}
\hline 31. & $\begin{array}{l}\text { Mørk, T., Bech-Larsen, T., } \\
\text { Grunert, K. G., \& Tsalis, G. }\end{array}$ & 2017 & Denmark & $\begin{array}{l}\text { Collectivistic values affect consumers' attitudes } \\
\text { toward organic products also in the } \\
\text { institutional/public setting. }\end{array}$ \\
\hline 32. & $\begin{array}{l}\text { Nuttavuthisit, K. and } \\
\text { Thøgersen, J. }\end{array}$ & 2017 & Thailand. & $\begin{array}{l}\text { Mistrust in the control system and in the } \\
\text { authenticity of food sold as organic has a significant } \\
\text { negative impact on self-reported buying behavior. }\end{array}$ \\
\hline 33. & $\begin{array}{l}\text { Pagliarini, E., Laureati, M., } \\
\text { \& Gaeta, D. }\end{array}$ & 2013 & Italy & $\begin{array}{l}\text { Organic and conventional wines differed } \\
\text { marginally in the intensity of sensory descriptors } \\
\text { and these differences did not influence consumers } \\
\text { liking. }\end{array}$ \\
\hline 34. & Paul, J. and Rana, J. & 2012 & India & $\begin{array}{l}\text { Health, availability and education positively } \\
\text { influence consumer's attitude towards buying } \\
\text { organic food products. }\end{array}$ \\
\hline 35. & $\begin{array}{l}\text { Petrescu, D. C., Petrescu- } \\
\text { Mag, R. M., Burny, P., \& } \\
\text { Azadi, H. }\end{array}$ & 2017 & Romania & $\begin{array}{l}\text { Consumers perceive farmers' markets and self- } \\
\text { production products as main purchase } \\
\text { sources/locations of uncertified organic food. }\end{array}$ \\
\hline 36. & $\begin{array}{l}\text { Pino, G., Peluso, A., and } \\
\text { Guido, G. }\end{array}$ & 2012 & Italy & $\begin{array}{l}\text { Food safety and health concerns influence the } \\
\text { purchase intentions of occasional consumers. } \\
\text { However, ethical motivations affect the purchase } \\
\text { intentions of the regular buyers. }\end{array}$ \\
\hline 37. & Rahnama, H. & 2017 & Iran & $\begin{array}{l}\text { For women, social and emotional value do not have } \\
\text { a significant impact on organic food choice. }\end{array}$ \\
\hline 38. & Rödiger M., \& Hamm, U. & 2015 & n.a.* & $\begin{array}{l}\text { Organic food prices are a major barrier to purchase, } \\
\text { however the organic market volume is growing and } \\
\text { results for the price-quality relationship indicate } \\
\text { reasonable opportunities for future organic markets } \\
\text { in the light of trends in consumer attitudes. }\end{array}$ \\
\hline
\end{tabular}


Please cite as: Asioli, Daniele; Aschemann-Witzel, Jessica; Caputo, Vincenzina; Vecchio, Riccardo; Annunziata, Azzurra; Næs, Tormod; Varela, Paula. Making sense of the "clean label” trends: a review of consumer food choice behavior and discussion of industry implications Food Research International, 99, 58-71. https://doi.org/10.1016/j.foodres.2017.07.022

\begin{tabular}{|c|c|c|c|c|}
\hline 39. & Samant, S. S., \& Seo, H. S. & 2016 & United States & $\begin{array}{l}\text { Sustainability-related label claims (e.g. organic), } \\
\text { increase quality perception and acceptability of } \\
\text { chicken breast meat only when consumers are well } \\
\text { informed about the label claims. }\end{array}$ \\
\hline 40. & $\begin{array}{l}\text { Schleenbecker, R. and } \\
\text { Hamm, U. }\end{array}$ & 2013 & n.a.* & $\begin{array}{l}\text { Consumers consider healthier the organic products } \\
\text { carrying health claims. }\end{array}$ \\
\hline 41. & $\begin{array}{l}\text { Schuldt, J. P., \& Hannahan, } \\
\text { M. }\end{array}$ & 2013 & United States & $\begin{array}{l}\text { Consumers rate organic foods as less tasty than } \\
\text { conventional ones. }\end{array}$ \\
\hline 42. & Kottala, S. Y., \& Singh, R. & 2015 & n.a.* & $\begin{array}{l}\text { Sustainability issues such as biodiversity } \\
\text { preservation, natural resources conservation and } \\
\text { lower energy consumption, play a key role in } \\
\text { influencing consumers' attitudes and behavior } \\
\text { towards organic foods. }\end{array}$ \\
\hline 43. & $\begin{array}{l}\text { Silva, A. R., Bioto, A. S., } \\
\text { Efraim, P., \& de Castilho } \\
\text { Queiroz, G. }\end{array}$ & 2017 & Brazil & $\begin{array}{l}\text { When the quality and sustainability labels (e.g. } \\
\text { organic) were communicated. consumers increase } \\
\text { sensory scores and purchase intention. }\end{array}$ \\
\hline 44. & $\begin{array}{l}\text { Thøgersen, J., de Barcellos, } \\
\text { M. D., Perin, M. G., \& } \\
\text { Zhou, Y. }\end{array}$ & 2015 & $\begin{array}{l}\text { Brazil } \\
\text { China }\end{array}$ & $\begin{array}{l}\text { Environmental friendliness and universalism } \\
\text { values are strong motivations to buy organic } \\
\text { vegetables. }\end{array}$ \\
\hline 45. & $\begin{array}{l}\text { Van Loo, E. J., Caputo, V., } \\
\text { Nayga, R. M., Meullenet, J. } \\
\text { F., \& Ricke, S. C. }\end{array}$ & 2011 & United States & $\begin{array}{l}\text { Consumer WTP for organic chicken breast differs } \\
\text { between demographic groups as well as among } \\
\text { consumers with different purchasing frequency of } \\
\text { organic meat products. }\end{array}$ \\
\hline 46. & $\begin{array}{l}\text { Van Loo, E. J., Caputo, V., } \\
\text { Nayga, R. M., \& Verbeke, } \\
\text { W. }\end{array}$ & 2014 & Belgium & $\begin{array}{l}\text { Consumers prefer the national organic food logo, } \\
\text { certified by a private organization, compared to the } \\
\text { newly-introduced EU organic food logo. }\end{array}$ \\
\hline 47. & Van Loo, E. J., Caputo, V., & 2015 & United States & Consumers utility increases when one of the labels, \\
\hline
\end{tabular}


Please cite as: Asioli, Daniele; Aschemann-Witzel, Jessica; Caputo, Vincenzina; Vecchio, Riccardo; Annunziata, Azzurra; Næs, Tormod; Varela, Paula. Making sense of the "clean label” trends: a review of consumer food choice behavior and discussion of industry implications Food Research International, 99, 58-71. https://doi.org/10.1016/j.foodres.2017.07.022

\begin{tabular}{|c|c|c|c|c|}
\hline & $\begin{array}{l}\text { Nayga, R. M., Seo, H. S., } \\
\text { Zhang, B., \& Verbeke, W. }\end{array}$ & & & $\begin{array}{l}\text { in particular organic USDA, Rainforest Alliance } \\
\text { and Fair Trade, is present on the coffee package. }\end{array}$ \\
\hline 48. & $\begin{array}{l}\text { Van Loo, E. J., Diem, M. N. } \\
\text { H., Pieniak, Z., \& Verbeke, } \\
\text { W. }\end{array}$ & 2013 & Belgium & $\begin{array}{l}\text { Recognition and knowledge of EU organic logo are } \\
\text { relatively low among Belgian consumers; while } \\
\text { there is a much higher recognition of the private } \\
\text { organic certification logo. }\end{array}$ \\
\hline 49. & $\begin{array}{l}\text { Vecchio, R., Annunziata, } \\
\text { A., Krystallis, A., \& } \\
\text { Pomarici, E. }\end{array}$ & 2015 & Italy & $\begin{array}{l}\text { Young consumers are more informed of the organic } \\
\text { label compared to other sustainability labels. } \\
\text { Understanding and use of sustainability labels may } \\
\text { be inhibited by a lack of credibility of the labels, } \\
\text { but also by uncertainty about which organization } \\
\text { body is responsible for the certification. }\end{array}$ \\
\hline 50. & $\begin{array}{l}\text { Vecchio, R., Van Loo, E. J., } \\
\text { \& Annunziata, A. }\end{array}$ & 2016 & Italy & $\begin{array}{l}\text { Providing additional information on organic } \\
\text { regulations does not affect the consumers' WTP for } \\
\text { organic yogurt. Specific socio-demographic } \\
\text { variables such as gender, age, presence of kids in } \\
\text { the household and the need to follow a specific diet, } \\
\text { positively affect consumers' WTP for organic } \\
\text { yogurts. }\end{array}$ \\
\hline 51. & Zagata, L. & 2012 & $\begin{array}{l}\text { Czech } \\
\text { Republic }\end{array}$ & $\begin{array}{l}\text { The intention to purchase organic food is mainly } \\
\text { determined by the health aspects of the food } \\
\text { product. }\end{array}$ \\
\hline 52. & Zander, K. & 2014 & $\begin{array}{l}\text { Estonia, France, } \\
\text { Germany, Italy, } \\
\text { Poland and the } \\
\text { UK }\end{array}$ & Consumers' knowledge of the organic logo is low. \\
\hline 53. & Zander, K., Padel, S., \& & 2015 & Estonia, & Consumers show a great confusion about organic \\
\hline
\end{tabular}


Please cite as: Asioli, Daniele; Aschemann-Witzel, Jessica; Caputo, Vincenzina; Vecchio, Riccardo; Annunziata, Azzurra; Næs, Tormod; Varela, Paula. Making sense of the "clean label” trends: a review of consumer food choice behavior and discussion of industry implications Food Research International, 99, 58-71. https://doi.org/10.1016/j.foodres.2017.07.022

\begin{tabular}{|c|c|c|c|c|}
\hline & Zanoli, R. & & $\begin{array}{l}\text { France, Germany, } \\
\text { Italy, Poland and } \\
\text { the UK }\end{array}$ & $\begin{array}{l}\text { labels, indeed the shares of consumers in the survey } \\
\text { who recognized the fake logo as an organic logo } \\
\text { was high. }\end{array}$ \\
\hline 54. & $\begin{array}{l}\text { Zanoli, R., Scarpa, R., } \\
\text { Napolitano, F., Piasentier, } \\
\text { E., Naspetti, S., \& Bruschi, } \\
\text { V. }\end{array}$ & 2013 & Italy & $\begin{array}{l}\text { Ethical/environmental issues, animal welfare, local } \\
\text { origin and local breeds are relevant factors in } \\
\text { explaining WTP for organic beef. }\end{array}$ \\
\hline
\end{tabular}

*n.a.=not available since it is a review article which does not focus on specific countries. 
Please cite as: Asioli, Daniele; Aschemann-Witzel, Jessica; Caputo, Vincenzina; Vecchio, Riccardo; Annunziata, Azzurra; Næs, Tormod; Varela, Paula. Making sense of the "clean label” trends: a review of consumer food choice behavior and discussion of industry implications Food Research International, 99, 58-71. https://doi.org/10.1016/j.foodres.2017.07.022

Table A.2 - Selected papers concerning the factors that drive consumers' perceptions and preferences for natural food products.

\begin{tabular}{|c|c|c|c|c|}
\hline $\mathbf{N}^{\circ}$ & AUTHORS & YEAR & COUNTRY & MAIN FINDINGS \\
\hline 1. & $\begin{array}{l}\text { Abouab, N., \& } \\
\text { Gomez, P. }\end{array}$ & 2015 & France & $\begin{array}{l}\text { Consumers perceive food from handmade production as } \\
\text { more natural than food products produced from machine- } \\
\text { made production. Thus the level of humanization of the } \\
\text { production process impacts } \\
\text { naturalness perceptions. }\end{array}$ \\
\hline 2. & $\begin{array}{l}\text { Amos, C., Pentina, I., } \\
\text { Hawkins, T. G., \& } \\
\text { Davis, N. }\end{array}$ & 2014 & United States & $\begin{array}{l}\text { Consumers use 'natural' as a simple choice heuristic } \\
\text { feature, showing that products labeled natural contain } \\
\text { superior instrumental attributes and are perceived to be } \\
\text { less harmful and healthier than conventional. }\end{array}$ \\
\hline 3. & $\begin{array}{l}\text { Aschemann-Witzel, } \\
\text { J. \& Grunert, K. }\end{array}$ & 2017 & Denmark & $\begin{array}{l}\text { Consumers' attitudes towards functional foods were more } \\
\text { favorable for food categories perceived as natural versus } \\
\text { processed. }\end{array}$ \\
\hline 4. & $\begin{array}{l}\text { Berry, C., Burton, S., } \\
\text { \& Howlett, E. }\end{array}$ & $\begin{array}{c}\text { (in } \\
\text { press) }\end{array}$ & United States & $\begin{array}{l}\text { The provision of objective information regarding the } \\
\text { ambiguity of natural claims moderates the effects of these } \\
\text { claims on consumers' attribute inferences and product } \\
\text { evaluations. }\end{array}$ \\
\hline 5. & Binninger, A.-S. & 2015 & France & $\begin{array}{l}\text { Naturalness of food products has two main dimensions: a } \\
\text { more altruistic one, linked with environmentally friendly } \\
\text { and animal welfare aspects, and a more egoistic one, } \\
\text { related to a balanced diet and health as well as sensory } \\
\text { properties. }\end{array}$ \\
\hline 6. & $\begin{array}{l}\text { Coppola, A., \& } \\
\text { Verneau, F. }\end{array}$ & 2010 & Italy & $\begin{array}{l}\text { Consumers' perception of naturalness is highly } \\
\text { differentiated in relation to the type of food and to the }\end{array}$ \\
\hline
\end{tabular}


Please cite as: Asioli, Daniele; Aschemann-Witzel, Jessica; Caputo, Vincenzina; Vecchio, Riccardo; Annunziata, Azzurra; Næs, Tormod; Varela, Paula. Making sense of the "clean label” trends: a review of consumer food choice behavior and discussion of industry implications Food Research International, 99, 58-71. https://doi.org/10.1016/j.foodres.2017.07.022

\begin{tabular}{|c|c|c|c|c|}
\hline & & & & $\begin{array}{l}\text { degree of product processing. Food processing or } \\
\text { manipulation decrease the consumers' perception of } \\
\text { naturalness. }\end{array}$ \\
\hline 7. & $\begin{array}{l}\text { Devcich, D. A., } \\
\text { Pedersen, I. K., \& } \\
\text { Petrie, K. J. }\end{array}$ & 2007 & New Zealand & $\begin{array}{l}\text { Consumers with a higher number of modern health } \\
\text { worries, such as "drug-resistant bacteria”, "pesticides in } \\
\text { food" show a stronger preference for foods that contain } \\
\text { only natural ingredients. }\end{array}$ \\
\hline 8. & $\begin{array}{l}\text { Dickson-Spillmann, } \\
\text { M., Siegrist, M., \& } \\
\text { Keller, C. }\end{array}$ & 2011 & Switzerland & $\begin{array}{l}\text { Consumers risk perceptions related to chemicals in foods, } \\
\text { additives and contaminants, is positively correlated with } \\
\text { preference for natural food. }\end{array}$ \\
\hline 9. & $\begin{array}{l}\text { Dominick, S. R., } \\
\text { Fullerton, C., } \\
\text { Widmar, N. J. O., \& } \\
\text { Wang, H. }\end{array}$ & 2017 & United States & $\begin{array}{l}\text { Consumers perceive products with "all natural" label to } \\
\text { have improved taste and improved nutritional value. } \\
\text { Women are more receptive to the "all natural" label than } \\
\text { men and responses to the label vary for different food } \\
\text { categories. }\end{array}$ \\
\hline 10. & $\begin{array}{l}\text { Dubé, L., Fatemi, H., } \\
\text { Lu, J., \& Hertzer, C. }\end{array}$ & 2016 & $\begin{array}{c}\text { United States and } \\
\text { India }\end{array}$ & $\begin{array}{l}\text { Natural food is positively evaluated not only on its } \\
\text { healthfulness, but also on the attributes related to pleasure } \\
\text { and other esthetic experiences perception. There are cross- } \\
\text { cultural differences between Eastern and Western } \\
\text { populations in their perception and attitudes towards } \\
\text { naturally nutritious product connected to differences } \\
\text { existing in food culture. }\end{array}$ \\
\hline 11. & $\begin{array}{l}\text { Evans, de } \\
\text { Challemaison, B., \& } \\
\text { Cox, D. N. }\end{array}$ & 2010 & Australia & $\begin{array}{l}\text { Australian consumers perceive products with physical } \\
\text { changes, less processing, with ingredients described using } \\
\text { common named descriptors (instead of E-numbers) to be } \\
\text { more natural. }\end{array}$ \\
\hline 12. & Franchi, M. & 2012 & n.a.* & The term 'natural' is used as a brand representing \\
\hline
\end{tabular}


Please cite as: Asioli, Daniele; Aschemann-Witzel, Jessica; Caputo, Vincenzina; Vecchio, Riccardo; Annunziata, Azzurra; Næs, Tormod; Varela, Paula. Making sense of the "clean label” trends: a review of consumer food choice behavior and discussion of industry implications Food Research International, 99, 58-71. https://doi.org/10.1016/j.foodres.2017.07.022

\begin{tabular}{|c|c|c|c|c|}
\hline & & & & $\begin{array}{l}\text { healthiness, reliability and reassurance in terms of safety } \\
\text { and security of food to consumers. }\end{array}$ \\
\hline 13. & $\begin{array}{l}\text { Hemmerling, S., } \\
\text { Canavari, M., \& } \\
\text { Spiller, A. }\end{array}$ & 2016 & $\begin{array}{l}\text { France, Germany, } \\
\text { Italy, the } \\
\text { Netherlands, } \\
\text { Poland and } \\
\text { Switzerland }\end{array}$ & $\begin{array}{l}\text { Organic consumers reveal a positive attitude towards } \\
\text { natural food, but a negative sensory preference for the } \\
\text { more natural product, defined as “attitude-liking gap". }\end{array}$ \\
\hline 14. & $\begin{array}{l}\text { Hauser, M., Jonas, } \\
\text { K., \& Riemann, R. }\end{array}$ & 2011 & Switzerland & $\begin{array}{l}\text { Consumers perceive naturalness as a multidimensional } \\
\text { concept, which refers to sustainable, organic farming, } \\
\text { traditional farming methods, fresh ingredients, use of raw } \\
\text { materials and more time for preparing and cooking food. }\end{array}$ \\
\hline 15. & $\begin{array}{l}\text { Li, M., \& Chapman, } \\
\text { G. B. }\end{array}$ & 2012 & United States & $\begin{array}{l}\text { Students perceive natural claimed products as healthier } \\
\text { and safer than products that are not claimed to be natural. } \\
\text { Perceived risk represents an important reason for } \\
\text { naturalness preference. }\end{array}$ \\
\hline 16. & $\begin{array}{l}\text { Liu, R., Hooker, N. } \\
\text { H., Parasidis, E., \& } \\
\text { Simons, C. T. }\end{array}$ & 2017 & United States & $\begin{array}{l}\text { The presence of an all-natural front-of-pack label } \\
\text { improves consumers' perceptions of product quality and } \\
\text { nutritional content. } \\
\text { Additional information provided at the point of purchase } \\
\text { impacts on consumers' perceptions of quality and } \\
\text { nutritional content of all-natural labelled products. }\end{array}$ \\
\hline 17. & $\begin{array}{l}\text { Lunardo, R., \& } \\
\text { Saintives, C. }\end{array}$ & 2013 & France & $\begin{array}{l}\text { Consumers perceived high naturalness when the point of } \\
\text { purchase is considered natural. Moreover, the authority } \\
\text { which claims the naturalness of the product is of major } \\
\text { importance. }\end{array}$ \\
\hline 18. & $\begin{array}{l}\text { Magnier, L., } \\
\text { Schoormans, J., \& }\end{array}$ & 2016 & Denmark & $\begin{array}{l}\text { Consumers perceived naturalness of the product is } \\
\text { influenced also by the sustainability of the packaging. }\end{array}$ \\
\hline
\end{tabular}


Please cite as: Asioli, Daniele; Aschemann-Witzel, Jessica; Caputo, Vincenzina; Vecchio, Riccardo; Annunziata, Azzurra; Næs, Tormod; Varela, Paula. Making sense of the "clean label” trends: a review of consumer food choice behavior and discussion of industry implications Food Research International, 99, 58-71. https://doi.org/10.1016/j.foodres.2017.07.022

\begin{tabular}{|c|c|c|c|c|}
\hline & Mugge, R. & & & \\
\hline 19. & $\begin{array}{l}\text { McFadden, J. R., \& } \\
\text { Huffman, W. E. }\end{array}$ & 2017 & United States & $\begin{array}{l}\text { Women show a greater WTP for organic-natural than men. } \\
\text { Price premiums tend to increase as a result of specific } \\
\text { information. }\end{array}$ \\
\hline 20. & Rozin, $\mathrm{P}$. & 2006 & United States & $\begin{array}{l}\text { For consumers processing alone, without substantial } \\
\text { change, can degrade naturalness. }\end{array}$ \\
\hline 21. & $\begin{array}{l}\text { Rozin, P., Spranca, } \\
\text { M., Krieger, Z., } \\
\text { Neuhaus, R., Surillo, } \\
\text { D., Swerdlin, A., \& } \\
\text { Wood, K. }\end{array}$ & 2004 & United States & $\begin{array}{l}\text { A substantial part of the motivation for preferring natural } \\
\text { food products is ideational (moral or aesthetic), as } \\
\text { opposed to instrumental (healthiness/effectiveness or } \\
\text { superior sensory properties). }\end{array}$ \\
\hline 22. & $\begin{array}{l}\text { Rozin, P., Fischler, } \\
\text { C., \& Shields- } \\
\text { Argelès, C. }\end{array}$ & 2012 & $\begin{array}{l}\text { United States and } \\
\text { Europe }\end{array}$ & $\begin{array}{l}\text { Both ideational and instrumental reasons influence } \\
\text { consumers' attitudes towards natural food. There are very } \\
\text { few differences in the conception of natural food between } \\
\text { European and American consumers, highlighting that } \\
\text { demographic variables play a minority role in influencing } \\
\text { the attitude towards natural. } \\
\text { For consumers naturalness is defined principally by the } \\
\text { absence of certain negative intrinsic characteristics rather } \\
\text { than the presence of positive ones. }\end{array}$ \\
\hline 23. & Siipi,H. & 2013 & n.a.* & $\begin{array}{l}\text { The ambiguous nature of the current uses of term } \\
\text { "natural" represents a serious risk for consumers, } \\
\text { misunderstanding or equivocation. }\end{array}$ \\
\hline 24. & $\begin{array}{l}\text { Syrengelas, K., } \\
\text { Lewis, K. E., } \\
\text { Grebitus, C., \& } \\
\text { Nayga Jr, R. M. }\end{array}$ & 2017 & United States & $\begin{array}{l}\text { The providing of additional information on the effective } \\
\text { meaning of natural label has a positive impact on } \\
\text { consumer utility when consumers are not aware of the } \\
\text { definition of natural. }\end{array}$ \\
\hline
\end{tabular}


Please cite as: Asioli, Daniele; Aschemann-Witzel, Jessica; Caputo, Vincenzina; Vecchio, Riccardo; Annunziata, Azzurra; Næs, Tormod; Varela, Paula. Making sense of the "clean label” trends: a review of consumer food choice behavior and discussion of industry implications Food Research International, 99, 58-71. https://doi.org/10.1016/j.foodres.2017.07.022

\begin{tabular}{|l|l|l|l|l|}
\hline 25. & Thompson, D.B. & 2011 & n.a.* & $\begin{array}{l}\text { Ideological beliefs make greater contributions to the } \\
\text { preference for natural products than instrumental beliefs. }\end{array}$ \\
\hline
\end{tabular}

*n.a.=not available since it is a review article which does not focus on specific countries. 
Please cite as: Asioli, Daniele; Aschemann-Witzel, Jessica; Caputo, Vincenzina; Vecchio, Riccardo; Annunziata, Azzurra; Næs, Tormod; Varela, Paula. Making sense of the "clean label” trends: a review of consumer food choice behavior and discussion of industry implications Food Research International, 99, 58-71. https://doi.org/10.1016/j.foodres.2017.07.022

Table A.3 - Selected papers concerning the factors that drive consumers' perceptions and preferences for food “free from artificial additives/ingredients".

\begin{tabular}{|c|c|c|c|c|}
\hline $\mathbf{N}^{\circ}$ & AUTHORS & YEAR & COUNTRY & MAIN FINDINGS \\
\hline 1. & $\begin{array}{l}\text { Bearth, A., Cousin, } \\
\text { M.E. \& Siegrist, M. }\end{array}$ & 2014 & Switzerland & $\begin{array}{l}\text { Risk and benefits perceptions affect consumer' acceptance of } \\
\text { food additives. In addition, risk and benefits perception are } \\
\text { influenced by consumers' knowledge of regulation, their trust in } \\
\text { regulators, and their preference for natural products. }\end{array}$ \\
\hline 2. & $\begin{array}{l}\text { Bastian, Y., } \\
\text { Saltman, T., } \\
\text { Johnson, K., \& } \\
\text { Wilkinson, S. }\end{array}$ & 2015 & Aus & $\begin{array}{l}\text { Consumers considered natural flavourings and colours, and } \\
\text { additives associated with health benefits (e.g. vitamins, } \\
\text { minerals) more acceptable food additives, than winemaking } \\
\text { additives even commonly used and legally permitted additives, } \\
\text { such as tartaric acid, preservatives, oak chips, and tannins. }\end{array}$ \\
\hline 3. & I. F. & 2017 & & $\begin{array}{l}\text { Consumers attitudes toward and perceived behavioural control } \\
\text { of the consumption of food with additives, the impact of risk } \\
\text { perceptions plays an important role in determining an } \\
\text { individual's intention to take precautions to avoid consuming } \\
\text { foods that contain additives. In addition, the consumers' } \\
\text { attention to food additive scandal news and their perceived risk } \\
\text { determine their attitude toward consuming food with additives. }\end{array}$ \\
\hline 4. & $\begin{array}{c}\text { De Jonge, J., Van } \\
\text { Trijp, H., Jan Renes, } \\
\text { R., \& Frewer, L. }\end{array}$ & 2007 & $\begin{array}{c}\text { The } \\
\text { Netherlands }\end{array}$ & $\begin{array}{l}\text { Both optimism and pessimism about the food safety arise from } \\
\text { consumer trust in regulators and stakeholders in the food chain. } \\
\text { Consumer confidence in the food safety could be enhanced by } \\
\text { improving both consumer trust in societal actors, and consumer } \\
\text { safety perceptions of particular product groups. }\end{array}$ \\
\hline 5. & $\begin{array}{l}\text { Dickson-Spillmann, } \\
\text { M., Siegrist, M., } \\
\text { Keller, C. }\end{array}$ & 2011 & Switzerland & $\begin{array}{l}\text { General attitudes toward chemicals influence perceptions in the } \\
\text { food context. Consumers' dose-response insensitivity might lead } \\
\text { to an inappropriate perception of exposure hazards. }\end{array}$ \\
\hline
\end{tabular}


Please cite as: Asioli, Daniele; Aschemann-Witzel, Jessica; Caputo, Vincenzina; Vecchio, Riccardo; Annunziata, Azzurra; Næs, Tormod; Varela, Paula. Making sense of the "clean label” trends: a review of consumer food choice behavior and discussion of industry implications Food Research International, 99, 58-71. https://doi.org/10.1016/j.foodres.2017.07.022

\begin{tabular}{|c|c|c|c|c|}
\hline & & & & $\begin{array}{l}\text { Contaminants and additives in food are perceived differently } \\
\text { according to their origin. Women are more sensitive than men to } \\
\text { chemical exposure hazards. }\end{array}$ \\
\hline 6. & Haen, D. & 2014 & $\begin{array}{c}\text { The } \\
\text { Netherlands }\end{array}$ & $\begin{array}{l}\text { Ethical, aesthetic and cultural concerns are not recognized as } \\
\text { important drivers of public distrust about food additives which } \\
\text { are instead very relevant. }\end{array}$ \\
\hline 7. & $\begin{array}{l}\text { Kang, H.J., Kim, S., } \\
\text { Lee, G., Lim, H.S., } \\
\text { Yun, S. S. Kim, J. } \\
\text { W. }\end{array}$ & 2017 & $\begin{array}{c}\text { Republic of } \\
\text { Korea }\end{array}$ & $\begin{array}{l}\text { Consumers are concerned about the safety of using food } \\
\text { additives in processed foods and do not recognize these additives } \\
\text { as safe and useful materials as part of a modern diet. } \\
\text { Nutrition teachers and members of nongovernmental } \\
\text { organizations appeared to have a biased perception of food } \\
\text { additives, which may cause consumers to have a negative } \\
\text { perception of food additives. }\end{array}$ \\
\hline 8. & $\begin{array}{c}\text { Kubota, S., Sawano, } \\
\text { H., Kono, H. }\end{array}$ & 2017 & Japan & $\begin{array}{l}\text { Antioxidant-free label has a significant influence on consumer } \\
\text { preferences. Consumers who recognize food additive dangers } \\
\text { placed addition value on wine without antioxidants. However, } \\
\text { consumers who have knowledge of wine and food processing } \\
\text { tend to view antioxidant-free wine as lower in quality compared } \\
\text { to the wines made with the original manufacturing process. }\end{array}$ \\
\hline 9. & Lupton, D. A. & 2005 & Australia & $\begin{array}{l}\text { Consumers perceive that processing of foodstuffs and 'unnatural' } \\
\text { additives are the second relevant importance food characteristics } \\
\text { after dietary fat. }\end{array}$ \\
\hline 10. & $\begin{array}{l}\text { Shim, S.M., Seo, S } \\
\text { H., Youngja Lee, } \\
\text { Y., Moon, G. I., , } \\
\text { Kim, M.S., Park, J. } \\
\text { H. }\end{array}$ & 2011 & $\begin{array}{c}\text { Republic of } \\
\text { Korea }\end{array}$ & $\begin{array}{l}\text { A large part consumers expressed that information on food } \\
\text { additives was insufficient. They attributed this lack of } \\
\text { information to difficulties understanding the subject of food } \\
\text { additives and insufficient education. Almost half of the } \\
\text { consumers chose leaflets and pamphlets as preferable mediums }\end{array}$ \\
\hline
\end{tabular}


Please cite as: Asioli, Daniele; Aschemann-Witzel, Jessica; Caputo, Vincenzina; Vecchio, Riccardo; Annunziata, Azzurra; Næs, Tormod; Varela, Paula. Making sense of the "clean label” trends: a review of consumer food choice behavior and discussion of industry implications Food Research International, 99, 58-71. https://doi.org/10.1016/j.foodres.2017.07.022

\begin{tabular}{|c|c|c|c|c|}
\hline & & & & of information transmission. \\
\hline 11. & $\begin{array}{l}\text { Siegrist, M., } \\
\text { Sütterlin, B. }\end{array}$ & 2017 & Switzerland & $\begin{array}{l}\text { The use of E-number as symbolic information reported on the } \\
\text { label rather than chemical names reduce the perceived } \\
\text { naturalness of food additives. Consumers rely on symbolic } \\
\text { information when evaluating foods, which may lead to biased } \\
\text { judgments and decisions. }\end{array}$ \\
\hline 12. & $\begin{array}{l}\text { Szucs, V., Szabo, E. } \\
\text { \& Bana, D. }\end{array}$ & 2014 & Hungary & $\begin{array}{l}\text { Consumers' shopping decisions toward the "avoidance of food } \\
\text { additives" can be influenced with the rising of the trust against } \\
\text { the producers and the controlling authorities. }\end{array}$ \\
\hline 13. & $\begin{array}{l}\text { Tanaka, Y., } \\
\text { Kitayama, M., Arai, } \\
\text { S. \& Matsushima, } \\
\text { Y. }\end{array}$ & 2015 & Japan & $\begin{array}{l}\text { Consumer's emotions as anxiety and anger can be changed by } \\
\text { altering consumer's cognitions or perceptions. }\end{array}$ \\
\hline 14. & $\begin{array}{l}\text { Varela, P. \& } \\
\text { Fiszman, S. }\end{array}$ & 2013 & Spain & $\begin{array}{l}\text { Consumers have little knowledge and a relatively negative } \\
\text { perception about food additives. A strong association between } \\
\text { "industrially processed" food and additives/thickeners was } \\
\text { identified. }\end{array}$ \\
\hline 15. & $\begin{array}{l}\text { Wansink, B., Tal, } \\
\text { A., Brumberg, A. }\end{array}$ & 2014 & States & $\begin{array}{l}\text { Consumers have strong fears when added ingredients are } \\
\text { associated with less nutritious foods, while they can be reduced } \\
\text { if the history and function of ingredient are communicated. }\end{array}$ \\
\hline 16. & $\begin{array}{l}\text { Wu, M., Zhong, Y., } \\
\text { Shan, L. \& Qin, W. }\end{array}$ & 2013 & China & $\begin{array}{l}\text { Consumers' attitude towards behaviour, subjective norm and } \\
\text { information perception exerted moderate to high effect on food } \\
\text { scares, and the effects were also mediated by risk perceptions of } \\
\text { additive safety. }\end{array}$ \\
\hline
\end{tabular}


Please cite as: Asioli, Daniele; Aschemann-Witzel, Jessica; Caputo, Vincenzina; Vecchio, Riccardo; Annunziata, Azzurra; Næs, Tormod; Varela, Paula. Making sense of the "clean label" trends: a review of consumer food choice behavior and discussion of industry implications Food Research International, 99, 58-71. https://doi.org/10.1016/j.foodres.2017.07.022 